\title{
O palhaço Gadanho é nossa próxima atração: vem pro circo e para o choro com o "ás do violão"!
}

\author{
Humberto Amorim \\ UFRJ \\ humbertoamorim@musica.ufrj.br \\ Flavia Prando \\ CPF-Sesc-SP \\ prandoflavia@gmail.com \\ Jefferson Motta \\ CCSP-SP \\ jeffersonmotta@ymail.com \\ Ivan Paschoito \\ Legato \\ ipaschoito@gmail.com
}

Francisco Rosa Gadanho é mais um dentre as centenas de personagens pioneiros do violão brasileiro sobre o qual pouco se sabe. De sua eventual produção para o instrumento, a obra que ineditamente apresentamos neste artigo - o choro Caranguejo - é a primeira de que se tem notícia e, para além dela, são parcas as informações concretas sobre a sua biografia na literatura disponível. No caso do Palhaço Gadanho, seu nome artístico, esta lacuna parece significativa por se tratar de um dentre os mais afamados cômicos que, desde meados do século XIX, aproximaram os universos do circo e do violão no Brasil, um tema ainda infimamente estudado, mas cujo impacto parece ter sido decisivo para a disseminação do instrumento e de suas práticas a partir dos anos oitocentos. Além de apresentar e tecer uma breve genealogia do manuscrito e das fontes (sobretudo hemerográficas) encontradas, o artigo objetiva, em diálogo com parte da bibliografia de referência relacionada aos estudos circenses e suas intersecções com a música (SILVA, 2007; 2003; 1996; TINHORÃO, 2005, 2001; 1998; DAMASCENO, 1956), não somente levantar e analisar os traços biográficos disponíveis sobre Gadanho e conectar o personagem aos contextos e circuitos de atuação (por exemplo, os circos nos quais atuou e os palhaços com os quais conviveu, como Benjamim de Oliveira e Eduardo das Neves), mas também evidenciar alguns dos aspectos que tornaram o circo um espaço possivelmente importante no percurso histórico do violão no país, com reverberações na constituição, recriação e/ou disseminação de um repertório como acompanhante ou mesmo solista.

Palavras-chave: circo no Brasil, música nos circos, palhaços músicos, choros pioneiros para violão, palhaço Gadanho.

\section{Gadanho, the Clown, is our next star: come to the circus with the "Ace of the Guitar"!}

Francisco Rosa Gadanho is one of the many pioneering Brazilian guitarists about whom little is known. Of his works, the piece that we present in this article - the choro Caranguejo - is the first that is known and, besides it, concrete information about his biography is scarce in the available studies. In the case of Gadanho, the clown, his artistic name, this gap seems significant because he is one of the most famous characters that, since the end of the 19th century, brought the universes of the circus and the guitar closer, a subject still little studied, but whose impact seems to have been decisive for the dissemination of the instrument and its repertoire. In addition to presenting a brief genealogy of the manuscript and the sources raised (mainly in old newspapers) and dialoguing with a reference bibliography on the subject (SILVA, 2007; 2003; 1996; TINHORÃO, 2005, 2001; 1998; DAMASCENO, 1956), the article aims not only to analyze the biographical data available about Gadanho, connecting this character to the contexts and circuits 
of his network (for example, the circuses he worked for or the clowns he had contact with, such as Benjamim de Oliveira and Eduardo das Neves), but also to bring to light some of the aspects that made the circus such an important space in the historical trajectory of the guitar in the country, with reverberations in its repertoire as an accompanist or even soloist.

Keywords: circus in Brazil, music in circuses, musician clowns, music for guitar, pioneer "choros" for guitar.

\title{
Introdução
}

\begin{abstract}
- "Eu estava conversando, agora mesmo, com o Octavio, na esquina, quando aquele escaramelado de uma figa sae-se-me com esta: - Octavio, deixa graúna, vamos ao circo que isso por aí não tem mais futuro, e tu póde é acabá na pretoria... (EDMUNDO, 1938, p. 405)
\end{abstract}

Francisco Rosa Gadanho é mais um dentre as centenas de personagens do violão no Brasil sobre o qual pouco se sabe. De sua eventual produção para o instrumento, a obra que ineditamente apresentamos neste artigo - Caranguejo - é a primeira de que se tem notícia e, para além dela, são parcas as informações concretas sobre a sua biografia na literatura disponível. No caso do Palhaço Gadanho, seu nome artístico, esta lacuna parece significativa por se tratar de um dentre os mais afamados cômicos que, desde fins do século XIX, aproximou os universos do circo e do violão no Brasil, um tema ainda infimamente estudado e que parece ter sido capital para a disseminação do instrumento no país a partir dos anos oitocentos.

Gadanho também foi o único, dentre os seus pares palhaços-cantores-violonistas nascidos ou radicados no Brasil do século XIX, cujo registro de alguma obra para violão solo sobreviveu em partitura, legando-nos uma importante demonstração de como a presença e circulação de personagens em ambientes profissionais e espaços socioculturais pouco documentados e/ou estudados (como circos, cafés-cantantes, teatros de rua, praças, restaurantes, bares, etc.) não deixou de alcançar o repertório do instrumento.

$\mathrm{Da}$ bibliografia disponível, conseguimos elencar poucas e esparsas referências sobre Francisco Rosa. A mais significativa delas está em um dos números da revista $\mathrm{A}$ Voz do Violão, publicação que veio à tona no Rio de Janeiro depois do fim de sua antecessora, a também carioca $\mathrm{O}$ Violão, que teve dez números publicados entre dezembro de 1928 e novembro-dezembro de 1929.

Muito rica em informações, a revista [O Violão] se revelou verdadeira vitrine do violão carioca em suas diferentes frentes de atuação. Publicava artigos sobre a história do instrumento, perfis de artistas, acompanhamento 
de canções tradicionais, obras para violão solo, fotos de violonistas, anúncios de professores, venda de instrumentos, notícias do movimento de violão na cidade e em outros estados brasileiros, enfim, colocava o violão na pauta do dia, ensejando verdadeira discussão sobre as possibilidades de realização do instrumento e defendendo sobretudo a bandeira de 'nobilitar o violão'. (TABORDA, 2004, p. 72-73).

De vida mais curta, $A$ Voz do Violão teve três números mensais publicados respectivamente em fevereiro, março e abril de 1931, buscando pautar de forma ainda mais aberta as diversas práticas (profissionais e amadoras) e possibilidades de atuação que giravam em torno do instrumento no Brasil daquele período. Além de veicular partituras para violão solo e arranjos de canções populares e/ou regionais assinados por importantes nomes do instrumento, a revista também se dedicava a cumprir os seguintes propósitos: traçar panoramas históricos da trajetória do instrumento (no Brasil e no mundo); disseminar os preceitos da Escola de Tárrega; dar notícias de concertistas brasileiros e estrangeiros ou dos movimentos do violão em outros estados; veicular pequenas matérias sobre poetas, personagens vinculados ao carnaval ou intelectuais que guardavam relações com o instrumento; escrever resenhas sobre os registros de violão (solo ou acompanhante) na indústria fonográfica, rádio ou cinema; oferecer subsídios para o aprendizado de questões específicas (como afinar o instrumento ou reconhecer as posições de acordes e o campo harmônico de um determinado tom, por exemplo) sem a necessidade de um professor, em uma reverberação das publicações de métodos práticos que instigavam a cultura do "violão sem mestre"; ou ainda apresentar as estrelas do cancioneiro regional, consolidadas ou em ascensão, em matérias pomposas geralmente ilustradas por fotos. $\mathrm{Na}$ capa das três edições veiculadas, aliás, constam três mulheres ícones do período: Olga Praguer Coelho (1909-2008), Carmen Miranda (1909-1955) e Helena de Magalhães Castro (1902-1995). 
Figuras 1, 2 e 3. Capas dos números 1, 2 e 3 da revista $A$ Voz do Violão, destacando os nomes e rostos de Olga Praguer Coelho (n. 1), Carmen Miranda (n. 2) e Helena de Magalhães Castro (n. 3) no canto superior direito.
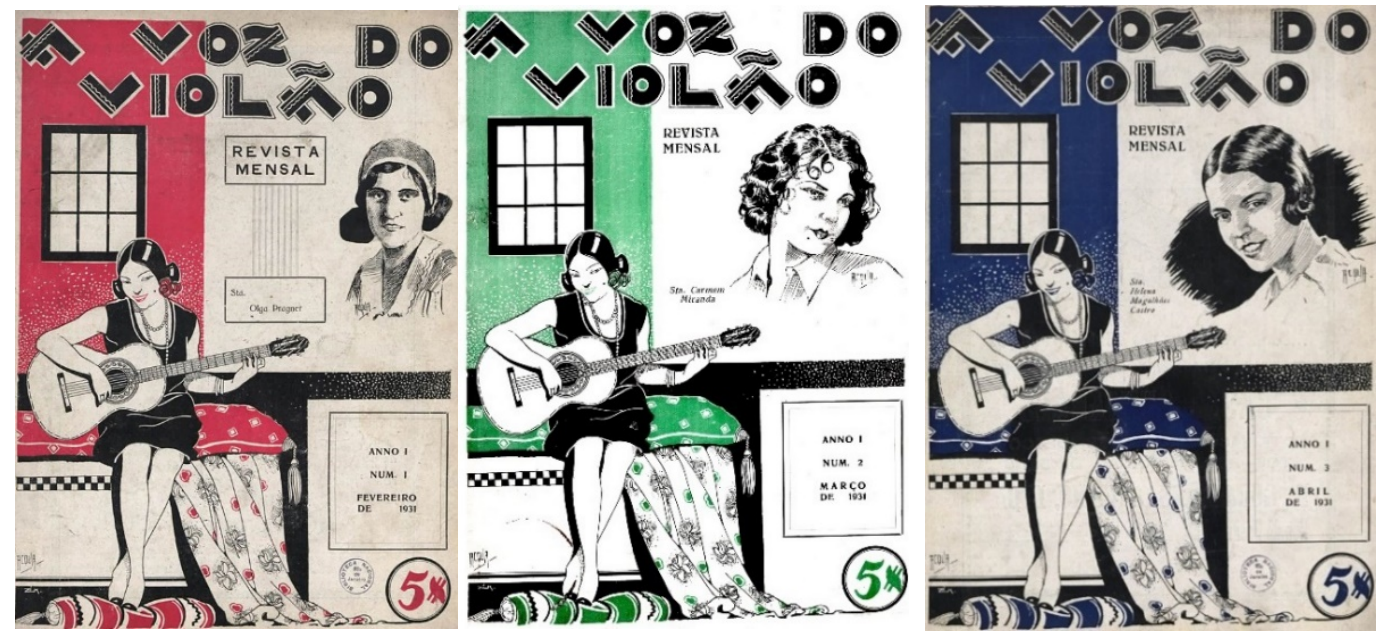

Fonte: A Voz do Violão (1931a; 1931b; 1931c) / acervo pessoal dos (a) autores (a).

Sem se fixar tanto no desafio de disseminar os preceitos técnicos de Tárrega e notabilizar a "escola oficial" do instrumento, A Voz do Violão abriu ainda mais o leque de temas abordados em comparação à revista $O$ Violão, abrindo perspectiva de pautar perfis de artistas que não haviam sido contemplados por sua antecessora. É neste sentido que, em seu número 1, o cômico regional J. Ferreira da Silva, de Taubaté (SP), ganha uma matéria de meia página a destacar não somente seus contratos com o Centro Artístico Regional e a gravadora Odeon (na qual realizou gravações - de canções autorais, inclusive - ao lado de Mozart Bicalho), mas também suas andanças pelo Brasil a partir de 1916, em périplos que percorreram estados como São Paulo, Rio de Janeiro, Minas Gerais, Espírito Santo e Bahia.

Assim que aparece, em um palco, um sujeito gordo, barrigudão, vestido à caipira e entoando ou relatando 'causos' sertanejos, num vozeirão grave de barítono, toda a gente já sabe: É o Ferreira da Silva.

E só em dizer-lhe o nome, o público começa a rir.

E ri, porque ele é realmente engraçado. ( $A$ VOZ DO VIOLÃO, 1931a, p. 23) 
Figura 4. Foto em perfil americano do cômico regional J. Ferreira da Silva.

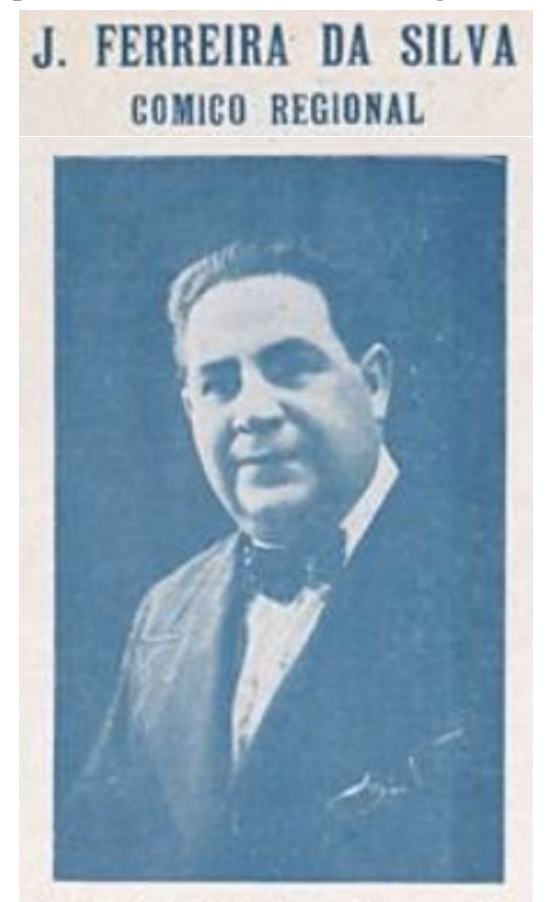

Fonte: (A VOZ DO VIOLÃO, 1931a, p. 23) / acervo pessoal dos (a) autores (a).

Em $A$ Voz do Violão, a ilustração de personagens relacionados ao violão que o utilizavam como ferramenta para provocar risos não se limitou aos cômicos regionais, mas incluíram também palhaços que atuavam (ou atuaram) em circos. Publicado em abril de 1931, aquele que viria a ser o derradeiro número da revista traz, literalmente na última página de conteúdo da edição (as duas páginas seguintes são de anúncios/propagandas), uma matéria exclusiva com o título: "As reminiscências de um velho palhaço", acompanhada de uma inédita fotografia - a única de que se tem notícia até o momento do palhaço Gadanho empunhando o violão. 
Figura 5 e 6. "O Velho Gadanha”. Foto e chamada da matéria sobre "Gadanha", a glória antiga dos picadeiros de circo".
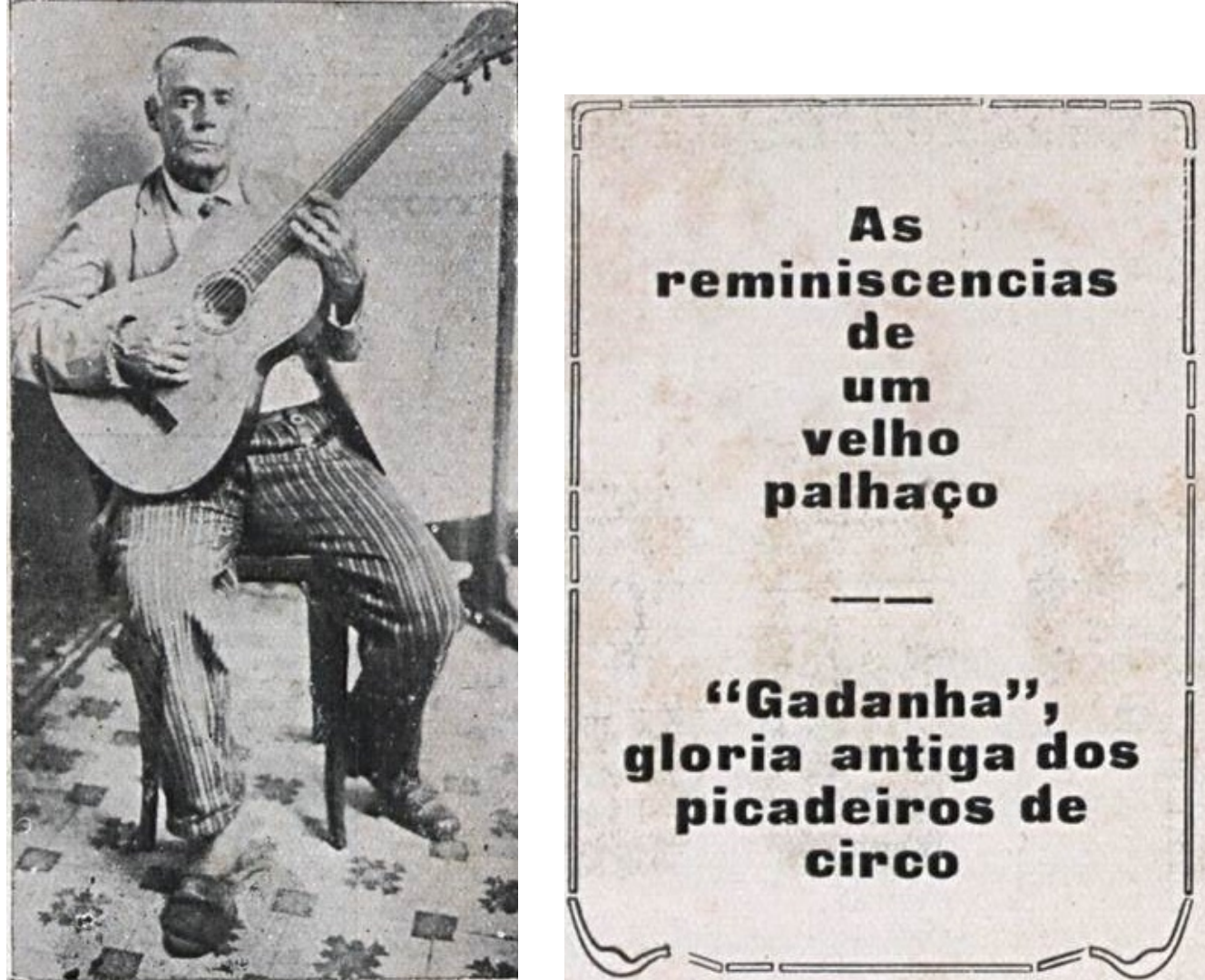

Fonte: (A VOZ DO VIOLÃO, 1931c, p. 30) / acervo pessoal dos (a) autores (a).

A foto é carregada de simbolismos, revelando um senhor tarimbado, de expressão séria e cabelos brancos nas laterais, e que, a despeito da humildade de sua calça listrada e sandálias de dedo (uma delas inclusive projetada para fora do pé), não deixa de vestir gravata e terno, este aparentemente puído na gola do punho direito, aproximando-se das veias sobressaltadas da mão que, rente ao cavalete, articula as cordas do violão. Dialogando com a imagem, o texto da matéria divide a abordagem do personagem em dois momentos: o passado de glória nos melhores circos da época e o presente miserável marcado pelos sinuosos desafios da sobrevivência. O longo e comovente trecho, apesar de carregar a tinta na leitura romantizada da trajetória do palhaço, merece ser transcrito integralmente pela quantidade de informações que podem ser depreendidas de seu conteúdo, explícita ou tacitamente:

\footnotetext{
${ }^{1}$ Cumpre notar a menção nominal ao palhaço finalizando com o "a": Gadanha. À exceção de Tinhorão (1998, p. 235), que reproduz as notícias sobre Francisco Rosa a partir da revista A Voz do Violão, todas as outras fontes levantadas se referem a ele utilizando "o" ao final do nome: Gadanho.
} 
- 'Gadanha'! Canta o 'Gadanha'!

As luzes do acetileno, de um branco intenso, refulgiam na areia do picadeiro. O circo era o melhor da época, a 'estrela', a célebre Rosita de la Plata, que ainda há quem lembre com saudade, atraía o mundo elegante daquele tempo. O circo era a grande atração. 'Gadanha', o popular e invejado Palhaço e cantor.

Fazia o sucesso que mais tarde veio fazer o saudoso Eduardo das Neves.

- Canta, 'Gadanha'! - bradava a multidão.

Forte, desempenado, magnífica voz atenorada; mais alto e desempenado nas roupas amplas e berrantes de palhaço, 'Gadanha' surgia na arena, violão em punho.

Dois, três acordes e a canção enchia o circo, que ouvia em silêncio, para estrondear depois em aplausos.

- 'Gadanha'! O 'Boiadeiro'

'Ó que triste vida

Passa o boiadeiro...'

Novos aplausos.

- 'Gadanha'! Canta a 'Mulata'!

'Mostraram-me um dia

Na roça dançando...'

Correu mundo o 'Gadanha' - Francisco Rosa. Foi um dos grandes 'capoeiras' do seu tempo e praça do Corpo de Bombeiros, onde aprendeu o violão, cantando em serenatas, o que lhe valeu a vida nômade dos circos. Belo, valente, bom violonista, magnífica voz, teve fortuna, teve glórias, teve amores... Tudo passou. A vida é assim.

- Ó 'Gadanha'! Canta lá uma cousa, ó velho arrenegado...

Já não é mais o picadeiro com a areia refulgindo à luz do acetileno. $\mathrm{O}$ ambiente é enfumaçado, morno: uma feia casa de pasto barata. A voz do velho e $A$ Voz do Violão, rachado, de cordas gastas, morrem entre os gritos do caixeiro 'cantanto a lista' e o rumor dos pratos...

Que há de fazer o velho palhaço se tem que viver? E só, que há muito lhe morreram a companheira e o filho.

Só, não: tem um violão que o acompanha há trinta anos. Na glória e na miséria. Deu-lhe a $A$ Voz do Violão, um violão novo, que canta como o outro já cantou; o velho levou também consigo o antigo companheiro.

Volta às casas de pasto. É a luta pela vida.

Não lhe pedem o 'Boiadeiro', nem a 'Mulata', os dois sucessos de antigamente; querem cousas ao gosto do auditório. E 'Gadanha' canta uns versos seus que acabam assim:

'A velhice é uma desgraça,

E sempre, sempre será:

Nos tira todos os mimos

Que a natureza nos dá.

Primeiro nos tira a vista

Do ouvido nos foge o som...

Depois... lá se vai o resto

Com tudo, tudo o que é bom!...'

Dão-lhe nickeis. Riem. Ele ri também, como riem todos os palhaços velhos. Aquela gente que ri, quer entender as reticências dos versos; não entende a dor de uma saudade.

Além de apresentar e tecer uma breve genealogia do manuscrito e das fontes (sobretudo hemerográficas) encontradas, o artigo objetiva, em diálogo com parte da 
bibliografia de referência relacionada aos estudos circenses e suas intersecções com a música (SILVA, 2007; 2003; 1996; TINHORÃO, 2005, 2001; 1998; DAMASCENO, 1956), não somente levantar e analisar os traços biográficos disponíveis sobre Gadanho, mas também por em pauta alguns dos aspectos que tornaram o circo um espaço tão importante para o percurso histórico do violão no país, assim como para a disseminação de seu repertório (seja cumprindo a função de acompanhador ou solista).

\section{Respeitável público, prepare o coração: agora é a vez do circo, do palhaço e do violão!}

A presença dos palhaços no bojo sociocultural brasileiro desde os séculos XVIII e/ou XIX vêm sendo permanentemente esquadrinhada em importantes estudos da área (BOLOGNESI, 2003; GUERRA, 1968). Na relação com a música, de acordo com o pesquisador José Ramos Tinhorão, o advento do circo moderno e a constituição da figura do palhaço instrumentista-cantor só foram consolidados, na América Latina, "já bem entrado o século XIX":

[...] com a chegada das primeiras excursões de troupes vindas da Europa e dos Estados Unidos, essa apropriação da fórmula internacional [do circo], para criações regionais, aconteceu na década de 1840 na Argentina através da introdução, nos espetáculos de picadeiro, de elementos gauchescos, logo depois responsáveis pelo surgimento da variante circense local chamada de 'circo criollo'.

Criados para a diversão de novas camadas urbanas contemporâneas da Revolução Industrial - que viera provocar ao mesmo tempo a diversificação social e a concentração da massa dos trabalhadores nas cidades -, os circos europeus, e depois os norte-americanos, estabeleceram como tradição a divisão de seus palhaços em tipos estereotipados, conforme suas especialidades (clown inglês, clown acrobata, palhaço branco, etc.). E embora vários deles usassem em suas apresentações instrumentos musicais, seu objetivo não era exibir-se tocando ou cantando, mas fazer rir através da emissão de guinchos desafinados e sons estapafúrdios.

A grande contribuição sul-americana à criação do circo seria, afinal, o aproveitamento dos múltiplos talentos histriônicos e musicais exibidos pelos diferentes clowns europeus, para a criação de dois tipos locais que lhes sintetizariam todas as virtudes: o palhaço instrumentista-cantor (equivalente do chansonnier do teatro musicado) e o palhaço-ator (responsável pelo aparecimento da originalíssima teatrologia circense das canções representadas, até hoje ignoradas por historiadores e estudiosos do teatro)." (TINHORÃO, 2001, p. 56-57). 
Referência nos estudos sobre o circo no Brasil, Erminia Silva (2007, p. 117) contrapõe esta ideia ao afirmar que "a construção do espetáculo circense, inclusive do personagem palhaço, passou por constantes transformações e adaptações, o que leva a crer que não se pode entender os dois tipos a que se refere Tinhorão apenas como criações locais". Contudo, a própria pesquisadora considera as vantagens de tais definições para a compreensão dos contextos circenses na América Latina, particularmente em território brasileiro, onde os espetáculos, "se não eram originais, de fato acabaram por desenvolver características diferenciadoras das produções circenses europeias e americanas do final do século XIX e início do XX."

Ao categorizar um dos tipos de palhaços como "cantores-instrumentistas negros", Tinhorão afirma que estes personagens foram os "criadores [no Brasil] do equivalente do circo criollo argentino", fazendo, entretanto, uma ressalva em relação à atuação de Gadanho em função de sua "pele menos escura" e indicando que "os próprios palhaços brancos já haviam de certo modo iniciado a nacionalização do circo, através da sua transformação em espécies de chansonniers de picadeiro.” (2001, p. 62).

\begin{abstract}
Em verdade, os palhaços negros Benjamin de Oliveira e Eduardo das Neves foram apenas dois expoentes do 'circo crioulo' no Brasil - para usar no melhor sentido a expressão cunhada pelos argentinos -, mas outros de pele menos escura figurariam também entre seus contemporâneos, como o antigo mulato capoeira carioca Francisco Rosa [na verdade, Francisco era provavelmente italiano], o palhaço Gadanha, que cantava ao violão desde o repertório de modinhas do século XIX (como a famosa 'A Mulata', sobre versos do poema 'Canção', do poeta Gonçalves Crespo, por sinal também mulato até o repertório do próprio Eduardo das Neves. (TINHORÃO, 2001, p. 79).
\end{abstract}

Figuras 7, 8 e 9. Eduardo das Neves, Francisco Rosa Gadanho e Benjamim de Oliveira empunhando o violão. 

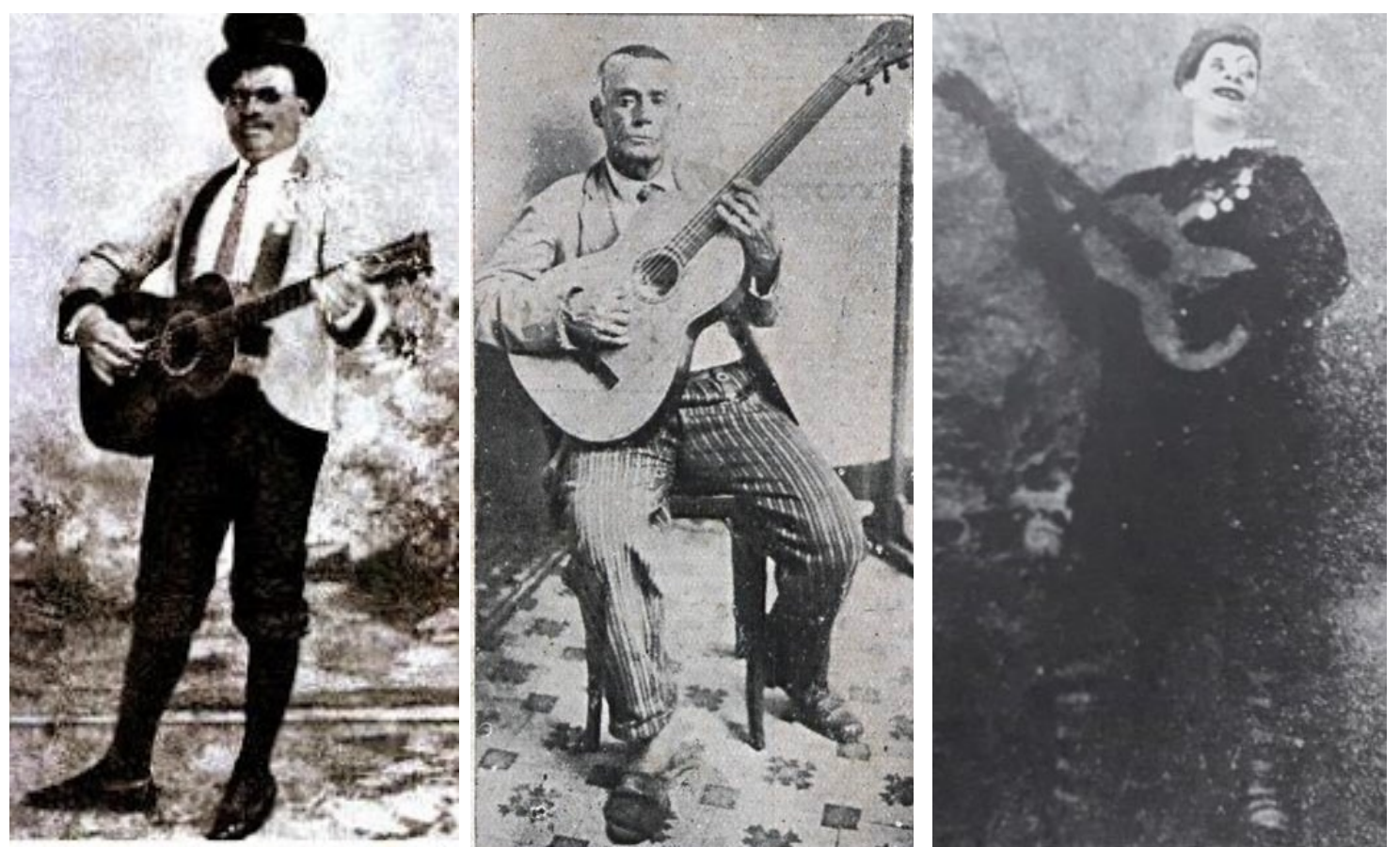

Fonte: Eduardo das Neves (à esquerda): Paraguassú (2016); Gadanho (ao centro): A Voz do Violão (1931, p. 30); Benjamim de Oliveira (à direita): Tinhorão (2001, p. 61).

Mais uma vez, Erminia Silva (2007, p. 121) rearticula a questão ao ponderar que "identificar certos gêneros musicais com grupos sociais, a partir de lógicas dicotômicas," não é uma forma adequada de abordar um objeto de estudo tão multifacetado, especialmente porque os dados "acabam por negar que uma determinada 'camada social' frequentasse um único espaço". ${ }^{2}$ Com isto posto, o importante para nós é destacar que, desde a segunda metade do século XIX, com os circos brasileiros desdobrando esta tradição circense estrangeira e criando as suas próprias especificidades, abundam os casos de palhaços instrumentistas-cantores (e que eventualmente também trabalhavam como palhaços-atores) empunhando o violão, objeto que por sua acessibilidade financeira, portabilidade, conexão com as práticas culturais urbanas e rurais em voga e ampla penetração social em todas as camadas, foi imediatamente assumido como o instrumento

\footnotetext{
${ }^{2}$ A pesquisadora também adverte que muitos dos processos circenses que, no Brasil, Tinhorão identifica apenas nas últimas décadas do século XIX, "já estavam presentes desde muito antes [...]. Além do mais, fandango, umbigadas e estalar dos dedos, e o resquício da dança espanhola árabe, misturada aos batuques africanos, não eram uma forma de música e dança realizada apenas pela população pobre da cidade (nem apenas pela população negra), mas também por outros grupos, como os circenses ou os ciganos, que muitas vezes se confundiam. Mello Moraes Filho, por exemplo, ao relatar um casamento cigano na década de 1850, descreve-o como um ritual no qual a música e a dança eram acompanhadas por requebros, castanholas, sapateados dos fandangos ao som das violas." (SILVA, 2007, p. 121)
} 
musical de excelência nos circos brasileiros, particularmente através das mãos destes personagens.

O sucesso de tais palhaços foi tamanho que alguns deles chegaram a ter seus próprios empreendimentos, caso de Eduardo das Neves, que, a partir de 1906, aparece "liderando já agora elenco próprio, em sociedade com João de Castro", em uma empresa batizada de "Circo-Teatro-Pavilhão Brasileiro" (TINHORÃO, 2001, p. 77). Um dado importante é constatar que, de fato, a atuação sociocultural destes personagens não se limitou aos picadeiros. A descrição de uma apresentação que o "Crioulo Dudu", epíteto de Eduardo das Neves, realizou em um clube frequentado pela elite financeira de São Paulo (CORREIO PAULISTANO, 1905, p. 2), em 1905 - mesmo ano, portanto, das últimas apresentações que realizou no célebre Circo François-, revela que a circulação destes personagens não se restringia às classes "menos privilegiadas" ou às lonas dos circos.

Clube de Regatas S. Paulo. Conforme fora anunciado, realizou-se ontem na pitoresca sede deste clube o imponente concerto da banda policial, regida pelo maestro Antão Fernandes. [...] A concorrência não podia ser melhor: ali estava o que São Paulo possui de mais distinto. Entre os intervalos de uma peça para outra, o Sr. Eduardo das Neves, em uma baleeira situada no meio do rio, cantou lindas e chorosas modinhas ao som de um belo acompanhamento de violão. Ao terminar qualquer modinha era o magnífico cantor coberto de palmas. (CORREIO PAULISTANO, 1905, p. 2).

E este parece ter sido um movimento de duplo sentido, já que não foram somente os personagens circenses reiteradamente convocados a animar as festas protagonizadas nos clubes, saraus e salões da elite, mas esta parcela financeiramente privilegiada da sociedade também se esbaldava frequentando as lonas dos melhores circos que animavam o cotidiano das cidades, o que conferiu ao repertório dos palhaços um grande poder de difusão nos mais variados espaços e estratos sociais, alcançando concomitantemente clubes ricos e serenatas de rua; grandes estruturas circenses e lonas mais humildes, já que, nos pequenos circos, palhaços cantores-instrumentistas de fama mais modesta reproduziam o repertório dos mais consagrados, retroalimentando um grande circuito de divulgação das músicas.

[...] os circenses brasileiros do período disputavam tanto a construção de novas linguagens culturais urbanas quanto o público dos diferentes setores sociais das cidades. Na sua forma de organização, apreendiam, recriavam, 
produziam e incorporavam referências culturais múltiplas e eram assistidos pelos trabalhadores, intelectuais, artistas e a população mais abastada. (SILVA, 2007, p. 21).

Em sua tese de doutorado, a pesquisadora Suzana Ferreira (2006, p. 59) sugere que estes processos levaram "as classes mais pobres [mas não exclusivamente elas] e de uma diversidade cultural bastante explícita a consagrarem lugares de recepção da sua produção artística", acrescentando que "o circo foi, até os anos [19]20, não apenas o espaço de praxe dos palhaços, malabaristas e etc., mas também o grande divulgador da música popular brasileira." E não se tratava apenas de configurar espaços próprios para a recepção deste repertório, mas identificar as figuras que, dentro do bojo sociocultural da época, melhor poderiam fazer a leitura, a síntese e a divulgação deste repertório adaptado e desdobrado a partir de cançonetas, zarzuelas, árias operísticas, modinhas, lundus, chulas, dobrados, quadrilhas, fandangos, schottisches, valsas, polcas e os diversos outros gêneros que compunham o caldeirão efervescente da vida musical brasileira na segunda metade do século XIX. Neste sentido, os palhaços instrumentistas-cantores foram, desde o princípio, os que assumiram a condição de timoneiros.

Tinhorão aponta que, no Rio de Janeiro, estes palhaços cantores-instrumentistas só tinham equivalência com os cantores vendedores de modinhas (2005, p. 168). Aliás, algumas das coleções de modinhas anunciadas nos jornais desde fins do século XIX demonstram uma estreita ligação deste repertório com aquele protagonizado pelos palhaços, indicando que esta relação não era de contraposição, mas de intersecção. As modinhas, portanto, também ganhavam sotaques próprios na voz e no violão dos palhaços circenses brasileiros desde a segunda metade dos anos oitocentos, pelo menos. Em outubro de 1898, por exemplo, quando a Livraria do Povo anuncia a publicação do Trovador Moderno, uma “assombrosa coleção de moderníssimas modinhas populares", veicula nos jornais cariocas a seguinte nota:

O Sr. Francisco Affonso dos Santos, colecionador deste grandioso livro, é um amador extremoso e insigne tocador de violão. Quase todas as modinhas do Trovador Moderno têm sido cantadas por ele, pelo célebre e popular Cadete da Cidade Nova, pelo Sr. Catullo da Paixão Cearense, Alvaro José Nunes, Eduardo das Neves e outros rapazes de bom gosto, conhecidos como PERFEITOS tocadores de violão. (A NOTÍCIA, 1898, p. 2, grifos originais). 
Desde então, foram raras as coletâneas que, em maior ou menor grau (e por vezes exclusivamente), não agregassem o repertório difundido por palhaços músicos, em anúncios que se espraiavam pela imprensa de várias regiões do país e propagandeavam o sucesso de sucessivas coleções de modinhas e lundus.

Figura 10. "A mais bonita e a mais completa coleção de modinhas, lundus e poesias, do repertório dos populares trovadores Eduardo das Neves e Bahiano, encontra-se na LYRA POPULAR BRASILEIRA, $2^{\mathrm{a}}$ edição, um volume de 338 páginas, com linda capa a cores.

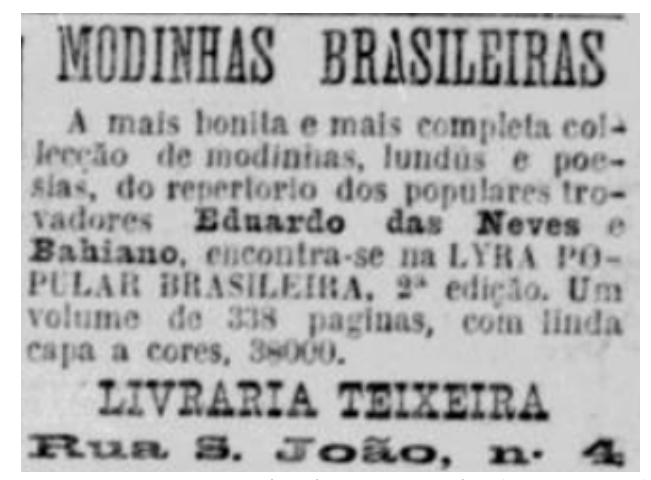

Fonte: O Commercio de São Paulo (1905, p. 3).

O caráter nômade e o grande poder de penetração social do circo permitiram uma ampla circulação da música de tradição popular antes do advento das gravações e das emissoras de rádio ${ }^{3}$, configurando-se em um "espaço de entretenimento que adquiriu grande importância na difusão da cultura e da canção popular.” (TABORDA, 2004, p. 88). Os palhaços com seus violões viajavam divulgando um repertório que, quando passou a ser registrado em disco, já era conhecido do público. A circulação dos palhaços cantores-instrumentistas facilitava não somente a venda de discos, mas assegurava a conquista de novos públicos. Assim, conforme os circos transitavam, iam espraiando o repertório e ampliando o potencial público consumidor das gravações. Quando Alexandre Gonçalves Pinto (Animal), em 1936, publica as suas reminiscências dos chorões antigos e descreve o palhaço Júlio de Assunção, pergunta quem não conhecia, à época, o repertório de modinhas e lundus tangido a partir de seu "mágico violão", reiterando a ampla popularidade alcançada por este personagem e sua "turma", que incluía Eduardo das Neves, Benjamim de Oliveira, Mário Pinheiro e muitos outros.

\footnotetext{
${ }^{3}$ A pesquisadora Erminia Silva abordou o assunto em suas pesquisas de mestrado e doutorado sobre a arte circense (SILVA, 1996; 2003).
} 
Quem não conheceu Júlio de Assunção, o grande palhaço de circo de cavalinhos que fazia vibrar as plateias com seu mágico violão? Cantando modinhas e lundus, apimentados e humorísticos. Quando entrava no picadeiro, era aclamado pois sabia dizer com graça e verve trocadilhos pilhéricos que a todos fazia ria. Júlio de Assunção foi aprendiz do palhaço Polidoro de gloriosa memória. Era da turma de Eduardo das Neves, Benjamin de Oliveira e Mário Pinheiro e muitos outros. (PINTO, 1936, p. 133).

Mas não eram apenas as modinhas, chulas e lundus que compunham o repertório dos palhaços cantores-instrumentistas. É necessário lembrar que os intercâmbios entre os ritmos e gêneros musicais em decantação (incluindo as "abrasileiradas" danças de salão europeias), com suas incorporações e transformações, estavam presentes nos diversos espaços urbanos em formação, e o circo passou a ser fundamental não somente na circulação dessa produção, mas também na transformação destes personagens em estrelas de "sucesso garantido", tornando-se canais vivos de difusão deste repertório para um corpo social amplo e diverso.

\begin{abstract}
Eram tocados e dançados em festas particulares, festas religiosas e em lugares públicos de onde ficavam conhecidos dobrados, quadrilhas e fandangos. As apresentações musicais desenvolvidas pelos cômicos cantores e tocadores de violão, as cenas cômicas e as pantomimas iam se tornando cada vez mais os números principais dos espetáculos circenses, transformando aquele que os realizavam, assim como os que os produziam, em sucessos garantidos e premiados. (SILVA, 2003, p. 183)
\end{abstract}

No início do século XX, a nascente indústria fonográfica brasileira (1902) captou e cooptou - este "espírito do tempo", não sendo por acaso que os primeiros nomes de sucessos da fonografia nacional tenham sido justamente os dos palhaços cantoresinstrumentistas que se acompanhavam ao violão: Baiano (Manuel Pedro dos Santos 18701944); Cadete (Manoel Evêncio da Costa Moreira 1874-1960); o próprio Eduardo das Neves (1874-1919) e Mário Pinheiro (c.1880-1923), sendo que este último é considerado o responsável por uma das primeiras gravações de violão solo realizada por um brasileiro $(1910)^{4}$.

\footnotetext{
${ }^{4}$ Mário Pinheiro lançou um disco de solo de violão, o Victor 98.989, com a música Petita (matriz B-9306), segundo a Discography of American Historical Recordings, gravado em 06 jul. 1910, realizada em Nova Iorque. Disponível em: https://adp.library.ucsb.edu/index.php/matrix/detail/200009417/B-9306-Petita, acesso em 03 out. 2020. O pesquisador Sandor Buys indica que, ao lado da gravação de Petita realizada por Mário Pinheiro, outras duas peças para violão foram gravadas por volta de 1910: Jaci e Sertanejo, um solo de violão possivelmente gravado por João Pernambuco; e Rio-grandense, de A. Palmieri, em gravação do próprio autor. Disponível em: https://sandorbuys.wordpress.com/2016/05/05/o-primeiro-solo-de-violao-gravado-no-brasil/
} 
Assim, o advento do circo permitiu que se consagrassem espaços de produção, recepção e circulação de um repertório amplo e variado que alcançou publicações e públicos de todos os recantos do país, além de eleger a figura dos palhaços cantoresinstrumentistas como a representante por excelência deste repertório indistintamente incorporado, desdobrado e/ou criado a partir de diversas matrizes culturais. Podemos sugerir, portanto, que o circo colaborou para o surgimento de uma articulação original no cancioneiro nacional, com a criação e difusão de gêneros e subgêneros (como o lunducanção ${ }^{5}$ ) que se tornaram decisivos para os desdobramentos da música brasileira no início do século XX. Mais do que isso, foi um espaço importante de profissionalização dos músicos, incluindo não somente cantores e violonistas acompanhadores, mas também personagens que, na trajetória do violão brasileiro, deixaram importantes contribuições na constituição de um repertório solista para o instrumento. Eduardo das Neves foi proprietário de um circo em São Paulo, por exemplo, responsável por recrutar músicos como Roque Ricciardi, o Paraguassú, Aníbal Augusto Sardinha, o Garoto, e Américo Jacomino, o Canhoto.

\begin{abstract}
Ainda com Paraguaçu, em 1907, Jacomino começa a se apresentar em cinemas como o Bresser, Braz-Bijou e o Éden, onde os ingressos custam 300 réis, e em teatros, circos e restaurantes como o Cascata, na esquina da Senador Feijó com a Quintino Bocaiúva. Essas apresentações são fundamentais pelos contatos que o violonista vai estabelecendo, além da prática em se apresentar em público. (ANTUNES, 2002, p. 52).
\end{abstract}

Erminia Silva (2007, p. 20) nos alerta que não se deve estudar "a história do teatro, da música, da indústria do disco, do cinema, e das festas populares no Brasil sem considerar que o circo foi um dos importantes veículos de produção, divulgação e difusão dos mais variados empreendimentos culturais", acrescentando que "os circenses atuavam

\footnotetext{
Acesso em 08 maio 2021.

5 "Tinhorão afirma que a originalidade e a animação que garantiram ao lundu sua adoção pelo público branco e sua transformação em quadro exótico nos palcos contribuíram, a partir de seu ritmo de frases curtas e sincopadas, para a criação de dois tipos de canções: o lundu de salão e o lundu popular dos palhaços de circo e cançonetistas do teatro vaudevillesco, de fins do século xix e início do xx. Como canção, ganhava as salas da 'classe média, e os salões das camadas mais altas', equiparando-se às 'modinhas italianizadas'. Entre as 'camadas mais baixas, o lundu continuaria a sobreviver de mistura com batuques e sambas como dança da área rural e algumas regiões (...) e, como canção, nas cidades, sob a forma de gênero humorístico, cultivado ao violão pelos palhaços de circo que ainda chegariam a gravá-lo em discos no início do século xx'.” (SILVA, 2007, p. 121). Como já observamos, Erminia Silva não coaduna com a perspectiva dicotômica que associa uma determinada dança ou gênero musical a um grupo populacional específico. Por isso, tomamos esses subgêneros listados por Tinhorão mais como indícios das permeabilidades culturais complexas e multifacetadas que ocorreram no período do que como categorias estanques de análise.
} 
num campo ousado de originalidade e experimentação", o que incluía divulgar e mesclar “os vários ritmos musicais [...]”. Direta ou indiretamente, este processo alcança alguns personagens capitais do violão brasileiro, desvelando um contexto mais amplo de "trocas de experiências e ressignificações"6 que também reverberou, direta ou indiretamente, no repertório brasileiro para violão solo. É deste contexto mais amplo que desponta o nome de Francisco Rosa, o palhaço Gadanho, circense responsável por conceber um dos choros para o instrumento mais antigos (anterior a 1912) de que se tem notícia até o momento.

\section{E o palhaço Gadanho, conhece? Puxa o Caranguejo que o nome aparece}

A primeira citação na bibliografia pesquisada a nos levar ao nome de Francisco Rosa Gadanho foi indireta, em um curioso caso no qual a obra acaba por anteceder o artista. Para situarmos o deslocamento, é necessário botar em pauta o nome de um outro personagem estrangeiro, Melchior Cortez (1882-1947), português radicado no Rio de Janeiro desde os nove anos, um dos mais ativos personagens do violão de concerto carioca ao longo da primeira metade do século XX e cuja contribuição pode ser sintetizada em uma tríplice perspectiva:

1) Como pedagogo, foi fundador da Academia Brasileira de Violão e professor de senhoritas da elite carioca, além de publicar três cadernos técnicos/didáticos e dar aulas regulares em pelo menos quatro importantes editoras/lojas musicais do período (Casa Beethoven, Guitarra de Prata, Casa Buschmann \& Guimarães e Casa Arthur Napoleão);

2) Como concertista, teve diversas apresentações documentadas pela imprensa carioca, com destaque para os concertos em duo com Joaquim Francisco dos Santos (1873-1935), o Quincas Laranjeiras, e a sua atuação em palcos oficiais importantes (como o Instituto Nacional de Música), sendo repetidamente adjetivado nos

\footnotetext{
${ }^{6}$ Os circenses, ao se apresentarem aqui e ali como acrobatas, ginastas, mágicos, domadores, cantores, músicos, autores e atores, vão realizando trocas de experiências e ressignificações com outros modos e produções artísticas que, por sua vez, também são múltiplos. (SILVA, 2007, p. 22).
} 
jornais como um "digno representante do violão clássico" (DIÁRIO DE NOTÍCIAS, 1933, p. 9);

3) Como autor (compositor, arranjador, transcritor, revisor), teve diversas de suas obras publicadas por editoras renomadas, no Brasil e na Argentina, desde 1909, pelo menos, convertendo-se no primeiro autor radicado no Brasil a publicar peças com especificidades idiomáticas, como tremolos de quatro notas (Souvenir du Pará) e scordaturas mais ousadas (Marche Louis XVI), assim como ter sido o responsável por traduzir no violão alguns gêneros musicais que ainda não haviam alcançado o repertório publicado por editoras brasileiras, tanto advindos de tradições clássicas (como a elegia Ilusão Perdida) quanto populares (como peças que fazem remissão ao fado, às árias populares espanholas e ao choro).

A inclusão de um choro nesta lista é decisiva para começarmos a situar a relação entre Francisco Rosa e Melchior Cortez (ou, ao menos, entre os dois choros que compuseram). O improvável cruzamento no Rio de Janeiro de personagens tão díspares - um palhaço-músico italiano e um violonista clássico português - começa a ganhar contornos mais nítidos quando Cortez publica o choro autoral Colibri pela Casa Romero y Fernandez, em Buenos Aires, com a seguinte indicação em nota de rodapé: "Esta muzica foi feita em 1912 para tocar com o chôro intitulado CARANGUEIJO.”. (CORTEZ, [s.d.], p. 1, grafia original).

Note-se, portanto, que a remissão a Francisco Rosa é indireta, já que Melchior menciona o choro Caranguejo sem citar o nome de seu autor. Até agora, não era possível dimensionar qual o grau de diálogo entre as obras ou resolver a questão da autoria, notadamente porque não existiam informações sobre a peça, tampouco rastros do paradeiro de seu autor. O novelo começou a se desenrolar quando descobrimos uma versão manuscrita de uma obra com título homônimo, com a caligrafia musical de Melchior Cortez, no arquivo passivo (ainda não catalogado) da Coleção Ronoel Simões/ CCSP. Nela, o nome de Francisco Rosa, o Gadanho, consta inequivocamente como autor. 

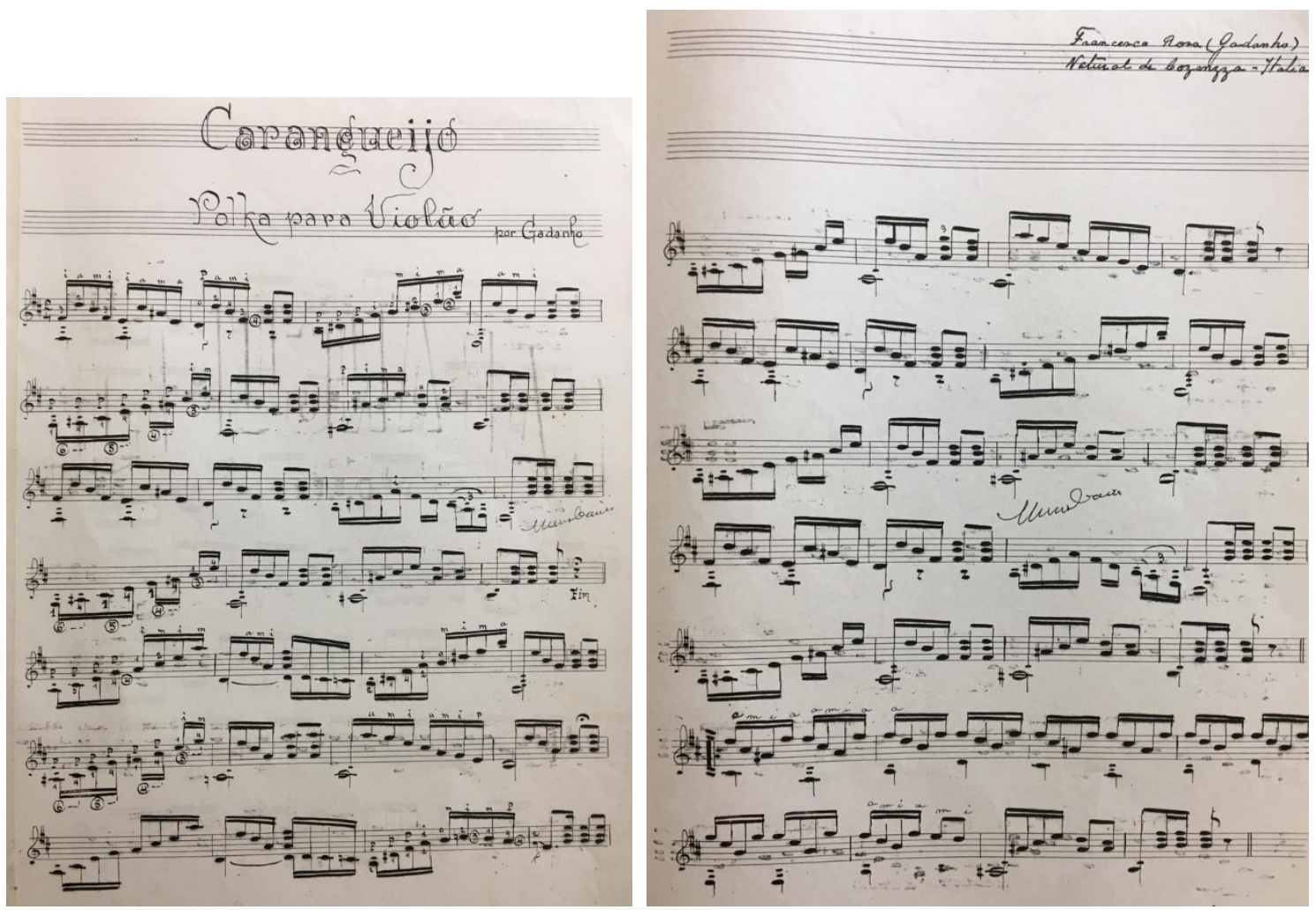

Fonte: Acervo passivo (ainda não catalogado) da Coleção Ronoel Simões / CCSP.

\section{1 'Prazer, Francisco Rosa Gadanho:}

\section{meus dados biográficos e atividades de antanho"}

No manuscrito recém-descoberto na Coleção Ronoel Simões, para além do título e subtítulo, constam no cabeçalho duas informações dignas de nota: a primeira, a de que o choro passa a ser referenciado como uma "polca para violão", desvelando que, no período de constituição do choro como gênero musical, por vezes houve variações terminológicas na designação de um mesmo repertório, fenômeno que já abordamos em estudos anteriores (AMORIM et al, 2021, p. 1-34); depois, pulula a indicação de autoria: "Gadanho", aparentemente um nome artístico. No canto superior direito da segunda página do manuscrito, a suspeita é ratificada com a inclusão do nome e sobrenome do autor por extenso, enquanto a alcunha passa a estar alocada entre parêntesis.

Figuras 13 e 14. Nome, sobrenome e apelido do autor de Caranguejo no manuscrito da peça. 

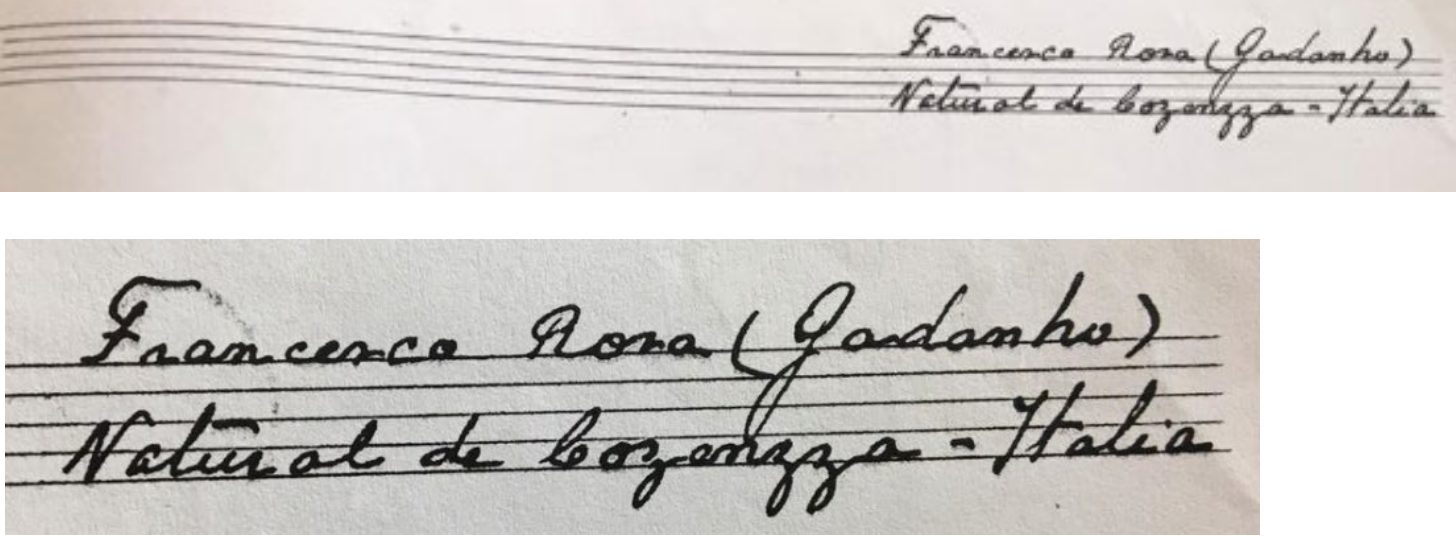

Fonte: Fonte: Acervo passivo da Coleção Ronoel Simões / CCSP.

Para além do nome e do apelido, esta nota presente no canto superior da página também nos deixa saber que a sua nacionalidade era italiana, natural de Cosenza, uma comuna da região de Calábria com cerca de 70 mil habitantes localizada ao sul da Itália. Sobre a família italiana e a que constituiu no Brasil, quase nada se sabe: a revista $A$ Voz do Violão (1931c, p. 30) relata que Francisco Rosa teve esposa e um filho, mas que havia perdido ambos há tempos. Em 1931, aos 59 anos, o antigo palhaço vivia absolutamente sozinho e lutava pela sobrevivência improvisando números musicais em um restaurante carioca de segunda categoria, dividindo a atenção dos clientes com o caixeiro que intermitentemente gritava a lista dos pratos do dia.

São desconhecidos os detalhes de sua chegada ao Brasil, como data e local de desembarque, mas suas primeiras atividades profissionais em território brasileiro foram documentadas em 1897, quando, já identificado como Palhaço Gadanho, o artista aparece como integrante do "grupo de bons artistas" da Companhia Casali \& Bavara, trupe que protagonizou espetáculos circenses no Pavilhão Serino, em Porto Alegre (RS), alcançando sucesso na cidade, a despeito de seu pequeno elenco.

Novidades e atrações melhores do que as do cinematógrafo e as do prestímano Amarante, foram sem dúvida, as apresentadas pela Companhia Casali \& Bavara, que, a 4 de abril [de 1897], estreou no Pavilhão Serino, à Praça das Carretas efetuando poucas funções, mas reaparecendo em agosto para uma temporada mais longa.

Dispondo de um grupo de bons artistas, como o contorcionista Durval, os acrobatas Pelage e Gaston, os equilibristas Modesto e Atilio Gani, a puladora Anselma e o Palhaço Gadanho - a troupe, conquanto pequena, faz ruido na cidade [...]. (DAMASCENO, 1956, p. 297, grifo nosso). 
Outros indícios reforçam a hipótese de que Porto Alegre foi um dos primeiros paradeiros fixos (senão o primeiro) de Gadanho no Brasil. De 1900 a 1903, um jornal gaúcho registrou o alistamento eleitoral anual de milhares de pessoas cadastradas na $3^{\mathrm{a}}$ seção estadual de eleitores ${ }^{7}$, incluindo, dentre eles, o seguinte cidadão: "Francisco Rosa Gadanho, 28 anos, filho de F. Gadanho, solteiro, [profissão] agência.” (A FEDERAÇÃO, 1900d, p. 3). No ano seguinte, as informações se repetem, mas, em 1902 e 1903, a referência à profissão de Gadanho modula de "agência" para "operário".

Figuras 15 e 16. Registros do alistamento eleitoral de Francisco Rosa Gadanho em Porto Alegre (RS).

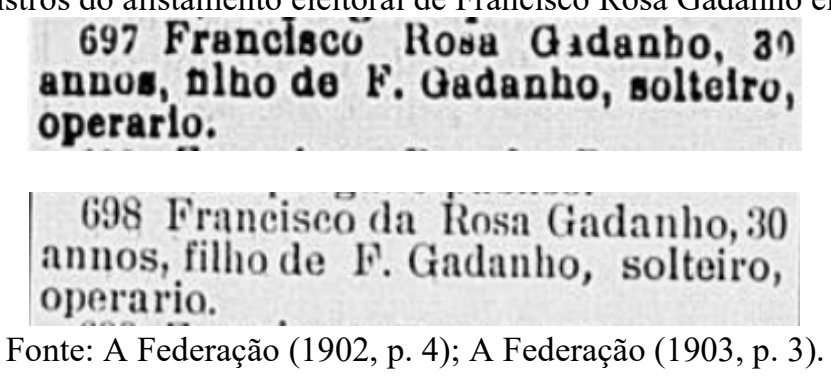

Nestes anúncios, observe-se que há algumas informações dúbias: primeiro, no último registro (1903), a inclusão de um "da" entre os nomes "Francisco" e "Rosa"; depois, que a idade não muda entre 1902 e 1903, algo que ocorrera nos anos anteriores. Provavelmente foram lapsos sem maior importância em uma listagem geral que contemplava o registro eleitoral manual de milhares de pessoas. $\mathrm{O}$ dado só tem alguma relevância porque, seguindo a lógica das idades mencionadas (28 anos em 1900, 29 em 1901, 30 em 1902 e supostamente 31 em 1903), é possível deduzir o provável ano de nascimento de Gadanho: 1872.

Importante destacar também as profissões mencionadas: Gadanho é descrito como agência (um ofício difícil de se traduzir nos dias de hoje) e operário, o que revela que, mesmo que tenha trabalhado em agrupamentos circenses antes (conforme comprova sua presença, em 1897, na Companhia Casali \& Bavara), o artista mantinha outras funções para sobreviver. O seu último registro eleitoral foi publicado em junho de 1903, indicando que, até esta data, a base de sua residência fora a capital gaúcha.

De fato, Athos Damasceno, em Palco, Salão e Picadeiro em Porto Alegre do Século $X I X$, corrobora esta hipótese ao comentar a participação de Francisco Rosa (então com

\footnotetext{
${ }^{7}$ Apesar dos milhares de registros, não constam nomes de mulheres na lista, uma vez que o Código Eleitoral brasileiro só passou a assegurar o voto feminino em 24 de fevereiro de 1932.
} 
28 anos) na inauguração de um café-cantante de Porto Alegre - o Odeon Variedades -, referindo-se a ele como "o apreciado Gadanho - lacrimejador de modinhas ao violão" (1956, p. 330).

\begin{abstract}
Neste 1900, instala-se um [Café-Cantante], em maio, na rua dos Andradas - o Odeon Variedades - do empresario Marcelino Dias Herrera.

A sua inauguração foi um sucesso em tôda a linha. O popular e querido ator Manoel Ponte, trazendo de Montevidéo um bem ensaiado grupo de artistas ligeiros, se encarrega de dar início às atividades do Odeon. E apresenta ao assanhado e impaciente público pôrto-alegrense um autêntico... ramalhete de rosas - senhorita Sanchez, senhoritas Carmensita e Angelita Tezeda, Senhorita Diamantina e senhora Gonzalez - a que se juntam três cravos- o próprio Ponte, o ator Sanchez e o cançonetista Girandur d'Órtoli... A esse ramalhete virão associar-se mais tarde a tiple Maria Salinas, a cantora Elvira Delamare, a dançarina Pepita Avelaneda, a cançonetista parisiense Mile. Lídia e, ao cabo, o apreciado Gadanho lacrimejador de modinhas ao violão. (DAMASCENO, 1956, p. 330, grifo nosso).
\end{abstract}

O jornal porto-alegrense A Federação confirma que, em 30 de maio de 1900, "continua a ser muito frequentado o Odeon Variedades e aplaudido o Manoel Ponte e a troupe que dirige.” (1900a, p. 2). No dia 12 de junho, o mesmo jornal (1900b, p. 2) indica que o empresário do café-cantante garantiu a viagem de "cinco novos artistas" contratados para trabalhar no estabelecimento, o que coincide com o número listado no livro de Damasceno em relação ao grupo integrado um pouco depois à companhia (Maria Salinas, Elvira Delamare, Pepita Avelaneda, Mademoiselle Lídia e Gadanho). Porém, apesar da ampliação do elenco e do aparente sucesso, a casa não teve vida longa, já que no dia 03 julho anunciou o encerramento de suas atividades e um leilão para a venda do espólio: "Deixou de funcionar o café-concerto - Odeon Variedades, estabelecido à rua dos Andradas pelo sr. Marcelino Dias Herrera.” (A FEDERAÇÃO,1900c, p. 2). É provável, portanto, que Gadanho tenha atuado no Odeon Variedades em junho de 1900. O dado é importante por situar a atuação do artista, já em princípios do século XX, em um café-cantante de Porto Alegre (RS), no sul do Brasil, demonstrando que, para além do circo, a sua atuação como palhaço, cançonetista e violonista encontrava abrigo em outros espaços socioculturais.

Mas Gadanho não se demorou muito em Porto Alegre. É provável que a vida nômade impelida pela atividade circense somada ao fato de que o artista ainda não tinha configurado família (seu estado civil consta invariavelmente como "solteiro" nos alistamentos eleitorais) o tenha levado a novos horizontes profissionais, inicialmente no 
estado do Rio de Janeiro, já que um mês depois da publicação de seu último registro como eleitor na capital gaúcha (em junho de 1903), o clown já aparece mencionado como um dos integrantes do célebre Circo Spinelli, em espetáculo realizado no Largo da Memória, cidade de Niteroi, e que teve a seguinte nota de divulgação veiculada na imprensa: "os clowns Benjamin, Cluset $^{8}$ e Gadanho prometem com as suas novas pilherias e modinhas fazer rir ao mais sizudo inglês." (O FLUMINENSE, 1903, p. 4).

Figura 17. Programa do Circo Spinelli em Niteroi (RJ), em 07 de julho de 1903.

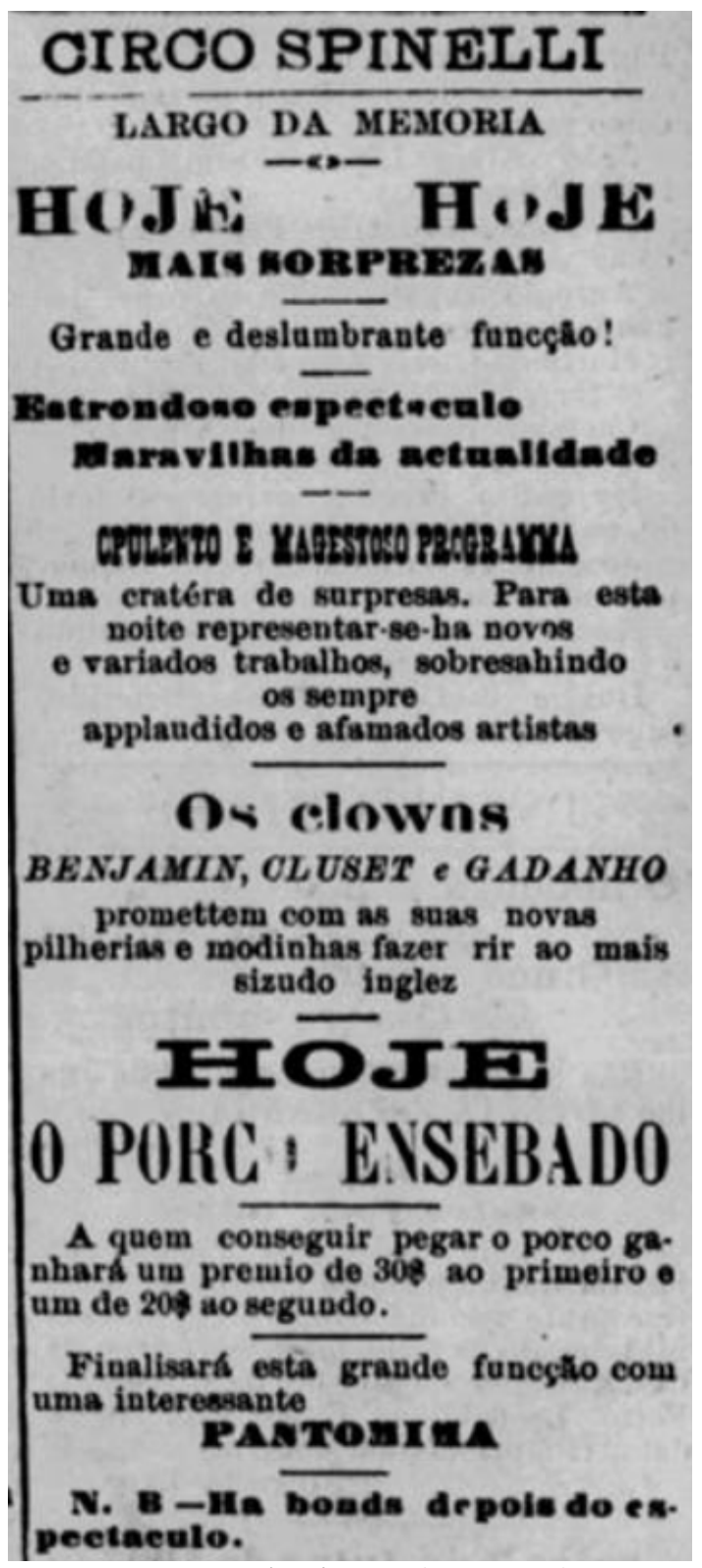

Fonte: O Fluminense (1903, p. 4).

\footnotetext{
8 Trata-se do clown argentino Manuel Cruzet (SILVA, 2007, p. 211), cuja grafia do nome, nos jornais da época, apresentou diversas variantes: Cruzetti, Kruzetti, Cluset e Cluzet.
} 
A passagem é importante não somente por incluir o repertório protagonizado pelos artistas - pilhérias e modinhas -, mas também por posicionar Francisco Rosa no Circo Spinelli, um dos mais importantes do período, trabalhando ao lado daquele que foi - ao lado de Eduardo das Neves (1874-1919) - um dos circenses de maior projeção entre fins do século XIX e primeiras décadas do XX: Benjamim de Oliveira (1870-1954)9.

Figuras 18 e 19. À esquerda, Benjamim de Oliveira apoiando o violão na perna direita; à direita, ao lado da mãe, empunhando o violão caracterizado como palhaço (com sua célebre maquiagem branca no rosto). Note-se que o artista tocava o instrumento em posição invertida, como canhoto.
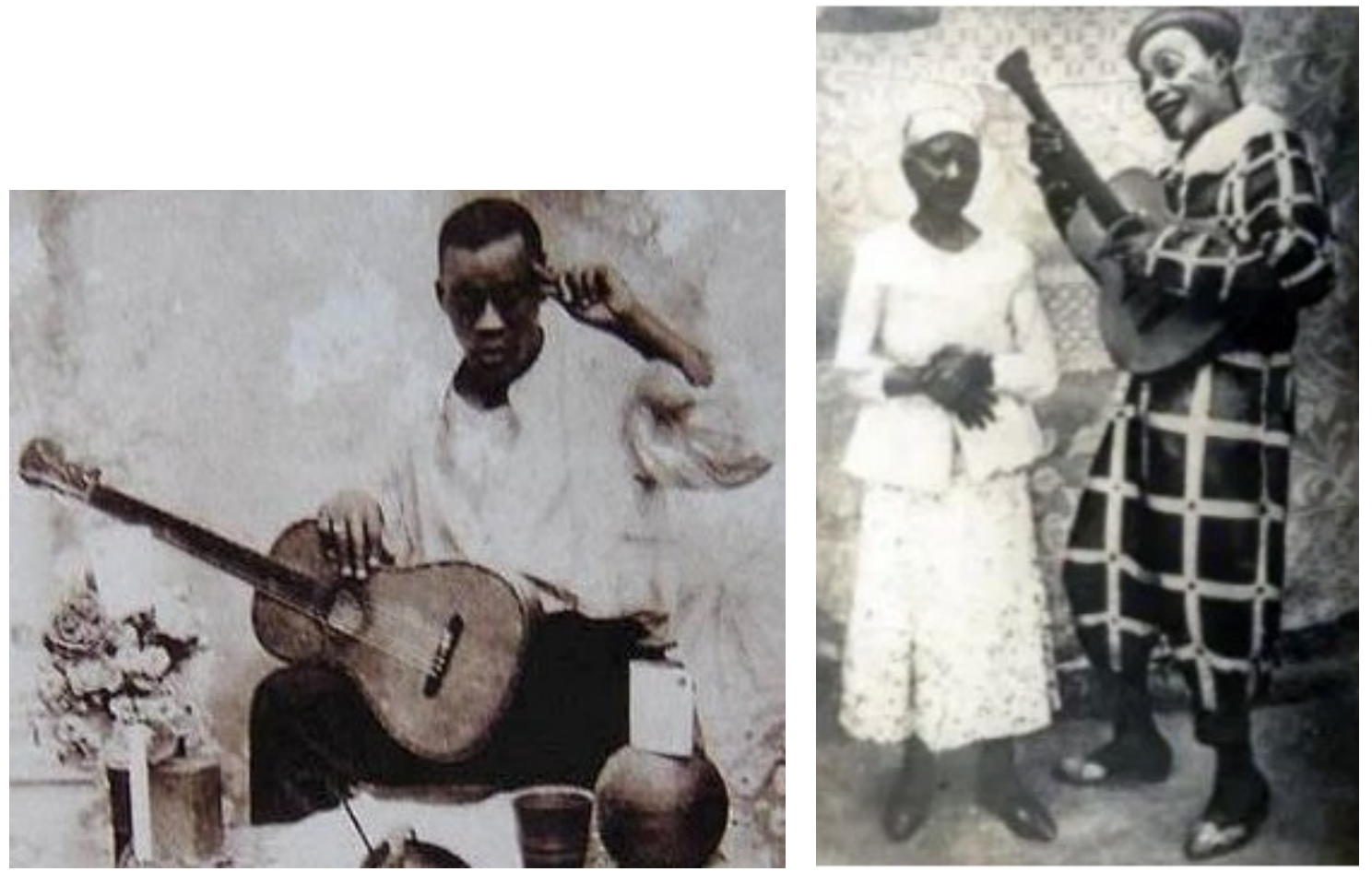

Gadanho, portanto, integrava uma rede de contatos mais ampla de palhaços músicos que, na passagem entre os séculos XIX e XX, compunham, atuavam e interpretavam em turnês com (e nos) circos, constituindo-se em “divulgadores e comerciantes privilegiados de seus trabalhos, usufruindo a própria capilaridade que o seu nomadismo permitia, conquistando novos públicos consumidores." (SILVA, 2007, p. 191).

Em algumas biografias, como as de João da Baiana, Mário Pinheiro, Baiano, Cadete, Catulo da Paixão Cearense, Eduardo das Neves, entre outros, constam participações em circos, levando a crer que, antes da virada

\footnotetext{
${ }^{9}$ Sobre este personagem e os contextos socioculturais do período, conferir o trabalho de referência de Erminia Silva (2007): Circo-Teatro: Benjamim de Oliveira e a teatralidade circense no Brasil.
} 
do século XIX, Benjamim de Oliveira tivesse cruzado com a maioria deles, fosse nos cafés, fosse nos palcos. Mas também se cruzaram frequentando os mesmos espaços dos batuques e pagodes das casas das mães-de-santo, na Cidade Nova, onde nasceram ou conviviam. Segundo Maria Clementina Pereira Cunha [(2001)], naquelas casas se 'mesclavam o baile, o sarau, a roda de samba, o candomblé, e por onde circulavam todas as esferas da sociedade (do esnobe literato ao policial ou ao partideiro capoerista da Saúde)'; entretanto, é possível afirmar que muitos dos palhaços cantadores de circo que já exerciam a profissão, ou que iriam exercê-la, já estivessem presentes naqueles encontros. Quando o Spinelli e Benjamim estabeleceram-se no Rio de Janeiro, a partir de 1905, muitos deles foram seus companheiros de trabalho como palhaços cantores, atores nas pantomimas, parceiros de autorias das músicas feitas para as cenas cômicas e peças. Benjamim também foi parceiro desses músicos na nascente indústria fonográfica, fazendo parte do primeiro elenco de cantores profissionais da Casa Edison, ao qual, além dos já mencionados acima, acrescentam-se Nozinho e Cadete.

De fato, as parcerias de Benjamin com outros palhaços músicos ocorreram, no Circo Spinelli, desde 1903. E Gadanho foi um deles, conforme demonstram diversos registros recolhidos ao longo do segundo semestre daquele ano: em 22 de agosto, por exemplo, os jornais cariocas informam que o circo iria estrear na rua de S. Cristovão (antiga Praça de Touros), apresentando, dentre os artistas, “o espirituoso palhaço Benjamin de Oliveira, o clown saltador Cruzetti [Cruzet], [e] o palhaço Gadanho, excêntrico, músico e cômico e um apreciado Tony, o imbecil”. (JORNAL DO BRASIL, 1903a). Aqui, vale destacar que o vocábulo "excêntrico" tinha uma conotação distinta se comparada à atual (de algo fora do padrão, distante do "centro"), indicando que o palhaço, na verdade, apresentava uma habilidade acima do padrão em um ou mais instrumentos musicais. No caso de Gadanho, o violão.

\footnotetext{
Não era novidade nos espetáculos circenses europeus os artistas tocarem instrumentos musicais. Os circos europeus que chegam ao Brasil e os que aqui vão se constituindo contaram com a presença marcante desses especialistas, chamados excêntricos. Muitos artistas que realizavam acrobacias de solo também as faziam tocando. Porém, o artista que desempenhava o palhaço era identificado como músico instrumentista, sendo chamado muitas vezes de cômico excêntrico, palhaço excêntrico e, cada vez com mais frequência, no final do século xix, de clown excêntrico. (SILVA, 2007, p. 116)
}

Cinco dias depois da estreia, em 27 de agosto, a imprensa registra que "as desopilantes entradas cômicas dos três queridos clowns Kruzetti [Cruzet], Gadanho e Benjamin arrancaram do público "boas gargalhadas". Nas funções seguintes, a trinca 
seguiu contagiando e fazendo "as delícias" da plateia, com Gadanho empolgando "com as suas novas cançonetas e lundus”. (JORNAL DO BRASIL, 1903b;1903c)

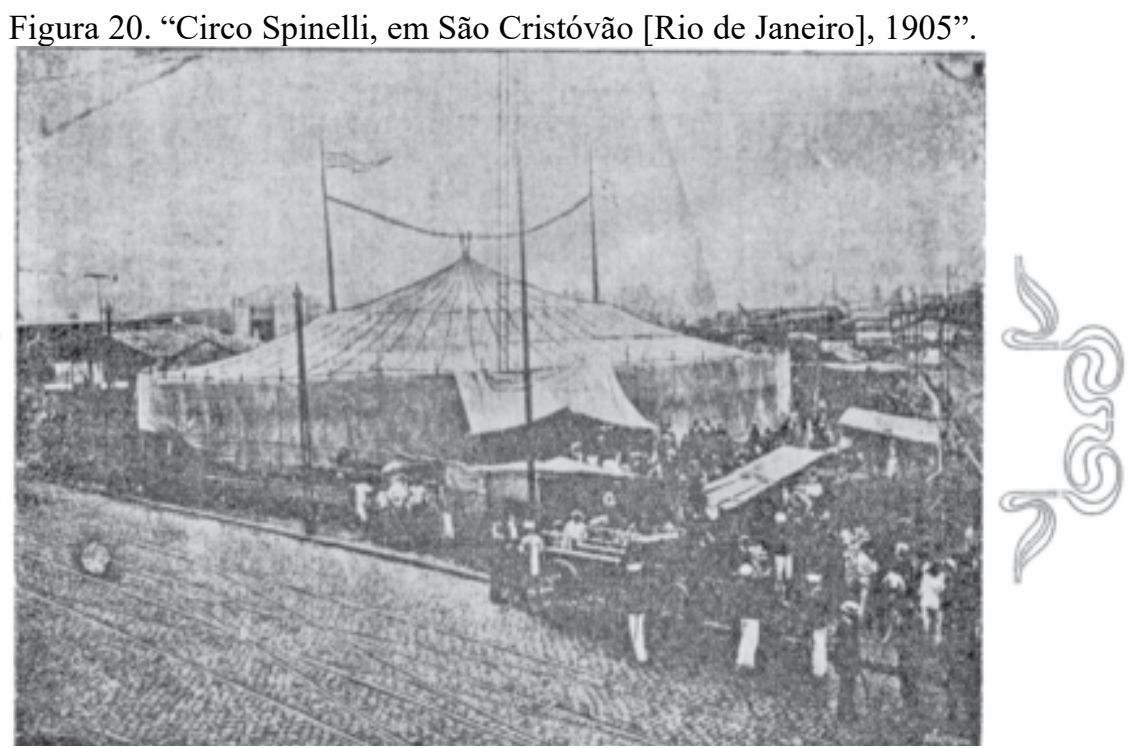

Fonte: Silva (2007, p. 251).

Figura 21. "O simpático clown Benjamin de Oliveira promete fazer as delícias da noite bem como o clown saltador CRUZET e o GADANHO com as suas novas cançonetas e lundus."

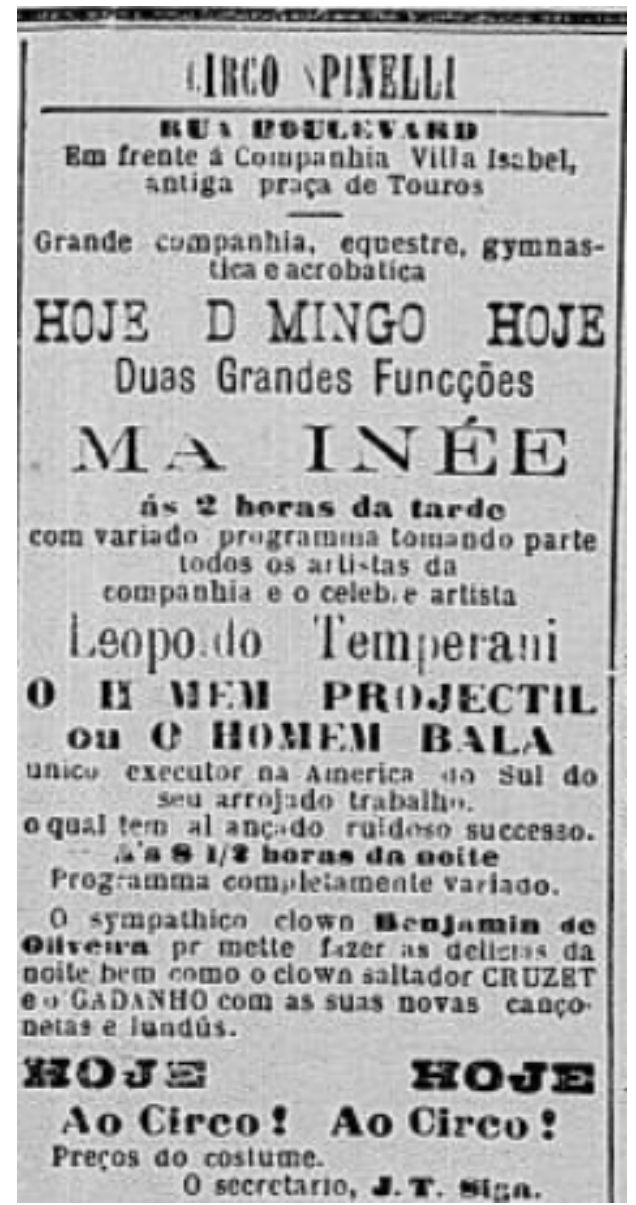

Fonte: Jornal do Brasil (1903d, p. 10). 
O sucesso da trinca seguiu por meses seguidos e, eventualmente, foi reforçado pela inclusão de um ou outro colega: "Circo Spinelli. [...] Os palhaços Benjamin, Cruset, Gadanho e Bacalhau prometem cousas do Arco da Velha." (JORNAL DO BRASIL, 1903e, p. 3). Algumas das produções eram grandiosas, como a "luxuosa e aparatosa pantomima Os Guaranys", inspirada e extraída das obras homônimas de José de Alencar (livro) e Carlos Gomes (ópera), escrita exclusivamente para o Circo Spinelli, companhia que se jactava de ser a única "com pessoal suficiente para cada um desempenhar o seu papel." De fato, as 70 pessoas em cena, os 22 quadros da apresentação e os 22 números musicais dão uma ideia da dimensão faustosa que um espetáculo circense do período poderia alcançar. Dentre os palhaços músicos, todos assumiram papeis dentre os "principais personagens": Benjamin de Oliveira, o "protagonista e ensaiador geral"; Gadanho, o "segundo chefe Itapaiu”. (JORNAL DO BRASIL, 1903f, p. 6).

Figura 22. "Soberbo programa - deslumbrante espetáculo" do Circo Spinelli, com o elenco e os detalhes da pantomima Os Guaranys.

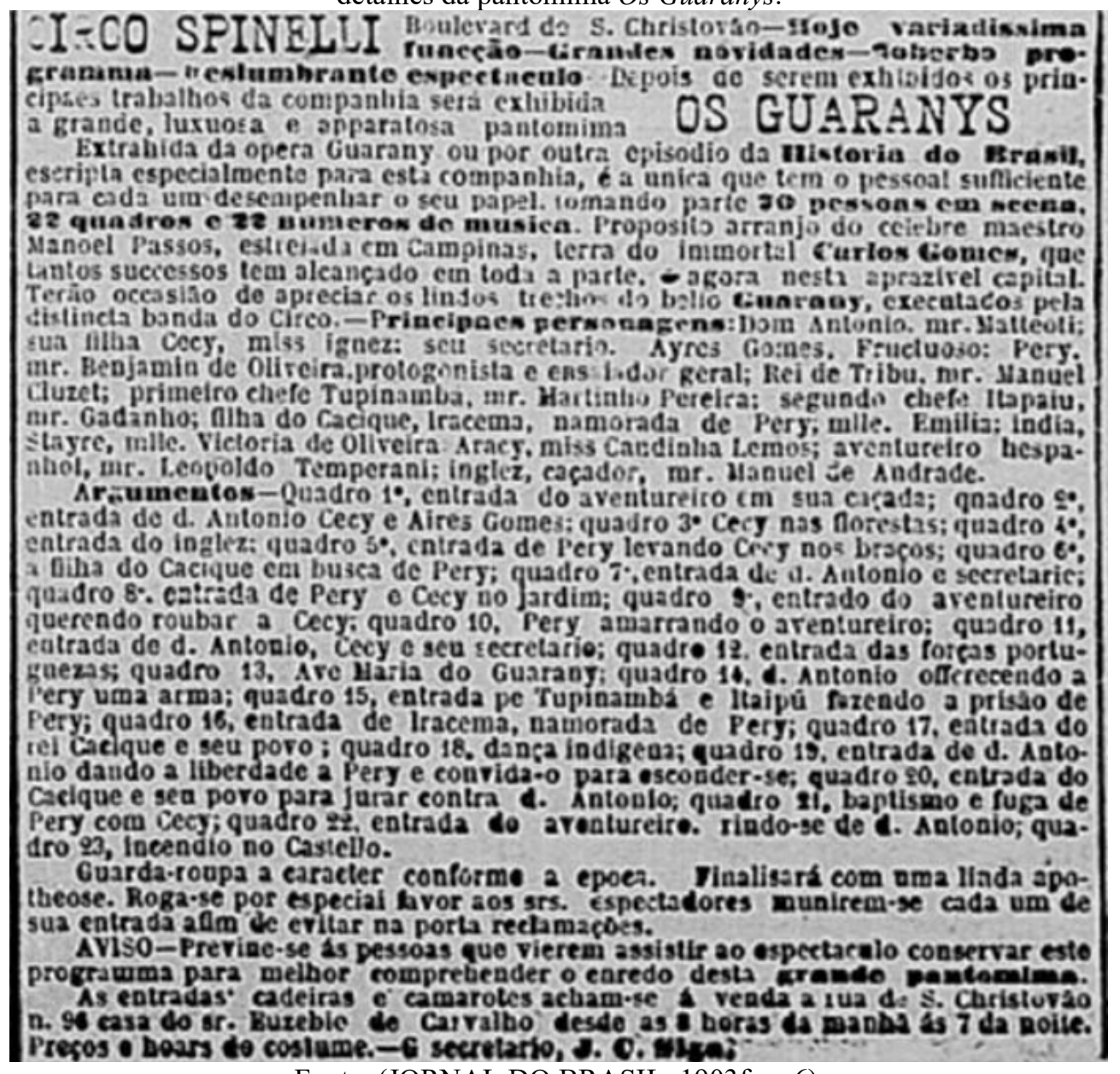

Fonte: (JORNAL DO BRASIL, 1903f, p. 6). 
Um olhar mais atento terá captado a presença do italiano Leopoldo Temperani nos anúncios do Circo Spinelli, considerado um dos introdutores, no Brasil, "do número do ‘canhão humano', no qual o artista era disparado de um canhão especial, como uma verdadeira bala humana, para ir agarrar-se a um trapézio, no alto do circo." (SILVA, 2007, p. 123). A família Temperani, de circenses italianos, trabalhava em território brasileiro desde a década de 1880, alternando temporadas em empreendimentos próprios - o Circo Temperani - com aquelas em que seus membros (ou parte deles) eram contratados e atuavam em companhias maiores, como o Spinelli ${ }^{10}$, em um movimento que, pelas diversas variáveis envolvidas na produção de um espetáculo, foi habitual nas relações estabelecidas entre os profissionais do circo.

\begin{abstract}
A mobilidade entre ser proprietário e artista contratado fazia (e faz) parte do próprio modo das relações no meio circense, no sentido mesmo da disponibilidade de oferta de trabalho; ser um ou outro dependia de um leque de fatores, desde crises econômicas, tragédias - como perda total dos circos devido a chuvas, tempestades, incêndios -, até dissoluções de sociedades ou por união através de casamento. (SILVA, 2007, p. 224-225).
\end{abstract}

O entendimento desta dinâmica mais ampla é fundamental para compreender os passos profissionais seguintes de Gadanho. As últimas apresentações que o palhaço realizou no Circo Spinelli ocorreram nos meses finais de 1903. No início do ano seguinte, o "excêntrico" artista passa a percorrer alguns estados brasileiros já como integrante do Circo Temperani. Durante a temporada de ambos no Spinelli, provavelmente o músico estreitou relação com o homem-canhão Leopoldo, diretor do Temperani, e foi convidado para integrar a companhia que sairia em turnê pelo Brasil, com um elenco descrito como "o mais seleto possível" e "composto de 25 artistas, entre os quais alguns de real celebridade" (A REPUBLICA, 1904a, p. 2). Em várias ocasiões, "Francisco Gadanho" é nominalmente citado dentre eles.

A estreia do Circo Temperani em Curitiba (PR) ocorreu em 10 de março de 1904. O jornal Diário da Tarde (1904a, p. 1) revela que a trupe, apesar das queixas sobre a falta de numeração das cadeiras, alcançou sucesso e o circo estava repleto de espectadores, com um bom desempenho dos clowns: “porém, apenas aplaudido o cançonetista

\footnotetext{
${ }^{10}$ Silva (2007, p. 377) anota que "até pelo menos dois anos antes de os Temperani e os Pery terem sido contratados pelo Spinelli, ambos tinham seus próprios circos". No fim de 1902, por exemplo, a autora nos informa que os Temperani passaram por Juiz de Fora (MG) e São Paulo (SP) com sua própria companhia.
} 
Gadanho, visto o outro, sr. Joaquim Gomes, ter caído na antipatia do público amante desse gênero de diversão." No dia seguinte, uma resenha mais ampla esmiuça detalhes da apresentação, ratificando que o circo estava abarrotado e "o povo empilhado, expremido, como sardinhas em tigela". Cumpre notar que mais da metade da crítica se dirige às atuações de Gadanho como cançonetista e violonista, destacando-se "nas cordas sonoras do violão, [...] tocado a vapor, tal a fúria com que dá conta do recado.” (DIÁRIO DA TARDE, 1904b, p. 1). É mais um indício de que, de fato, o artista justificava o epíteto de "excêntrico", dirigido aos palhaços que detinham habilidades diferenciadas em algum instrumento musical.

[...] Havia sede de facécias, de galhofas clownescas adubadas com um nadinha de pimenta malagueta e, por isso, apesar da birra em que o público tem um dos palhaços, a gargalhada explodiu aberta, feliz, atordoadora. Repercutiu mais feliz e aberta quando o sr. Gadanho repinicou os gadanhos nas cordas sonoras do violão. Houve bis; o homem voltou à arena, mais inspirado graças ao sucesso, atacando o famigerado Santos Dumão [Dumont]. Aplausos cobriram essa hedionda pachouchada patriótica e novos bis irromperam de um lado e d'outro.

Novo regresso à arena; agora uma versalhada comparando a mulher ao bond. Ao fim de cada copla, uma ovação. O belo sexo sorria discretamente, afiando o leque. Quando o cançonetista disparou: 'Toda a moça que se mete/ Na janela o dia inteiro,/ É bond que não trabalho/ Por falta de passageiro', dirigi os olhos para uma que sei janeleira como trinta: ria também da sátira, mas que risinho amarelo!

Afinal deixaram em paz o cançonetista e mais o seu violão que, seja dito de relance, parece tocado a vapor, tal a fúria com que dá conta do recado. Hoje, outra remessa de lundus e modinhas, inclusive aquela languorosa (acomodada, porém, ao sr. Gadanho): 'Morena, morena,/ Dos zóios castanhos/ Por ti no violão/ Esfólo os gadanhos.'

E vai ser o furor da função equestre, ginástica, acrobática, etc., etc., etc. Lapis (DIÁRIO DA TARDE, 1904b, p. 1).

Durante todo o mês de março, Gadanho seguiu recolhendo as melhores críticas dos jornais curitibanos pelas funções apresentadas no Circo Temperani: “o impagável clown cançonetista colheu novos aplausos.” (A REPÚBLICA, 1904b, p. 2). O sucesso na cidade foi tamanho que, no mês seguinte (abril), Gadanho recebeu seguidos espetáculos em seu “benefício" (DIÁRIO DA TARDE, 1904c; 1904d), ocasiões em que a divulgação do nome e habilidades de um determinado membro do elenco ficavam mais em evidência, inclusive gerando um retorno financeiro maior (tanto da companhia quanto das doações espontâneas do público). Um destes "benefícios" foi o penúltimo espetáculo realizado pelo circo em Curitiba, no dia mais disputado das apresentações (sábado), o que reafirma o prestígio angariado pelo palhaço na cidade: “O [espetáculo] de sábado, em benefício do 
cançonetista Francisco Gadanho foi muito concorrido, estando o circo repleto de espectadores incansáveis em aclamar o festejado clown.” (A REPÚBLICA, 1904c, p. 2).

De Curitiba, o Circo Temperani seguiu em excursão por outros estados brasileiros, muitas vezes passando por capitais e cidades interioranas cujos trajetos não foram documentados, o que torna difícil a apreensão de roteiros mais precisos. O que se sabe ao certo é que, pouco mais de dez dias após os últimos espetáculos no sul, a companhia se apresentou em Santos (SP), em 21 de abril de 1904, contando no elenco com "Gomes, Gadanho e Temperani - três clowns pilhéricos, saltadores." (CORREIO PAULISTANO, 1904b, p. 2)

Ao analisar conjuntamente estas fontes hemerográficas que anotaram as apresentações de Gadanho nos circos Spinelli e Temperani, podemos sugerir que, em relação às suas capacidades, alguns dos perfis retratados são recorrentes, especialmente dois: a destreza ao violão e as habilidades como cançonetista. Neste último quesito, cumpre notar a presença significativa em seu repertório de outro ícone circense do período: Eduardo das Neves (1874-1919), o "Crioulo Dudu”. Como observamos, alguns dos sucessos deste integravam o repertório daquele, incluíndo a famosa canção Santos Dumont (A Conquista do Ar), já na década de 1900 alvo de diversas gravações para diferentes formações ${ }^{11}$.

Como veremos, esta aproximação não é fortuita. Ao comentar o adjetivo utilizado por Athos Damasceno para definir o palhaço Gadanho - "lacrimejador de modinhas ao violão" -, Tinhorão reproduz as informações recolhidas na revista $A$ Voz do Violão sobre as atividades que Francisco Rosa desempenhou no Rio de Janeiro no fim de sua vida, estabelecendo um elo profissional entre ele e Eduardo das Neves para além do circo:

\begin{abstract}
["Lacrimejador Gadanho"] era o palhaço-cantor e violonista Francisco Rosa, $O$ Gadanha (que, tal como Eduardo das Neves, fora soldado do Corpo de Bombeiros do Rio de Janeiro), e que viria a terminar melancolicamente como garçon de uma casa de pasto carioca da década de 1930, usando agora a voz para 'cantar a lista', como era costume nos restaurantes modestos, onde os 'pratos do dia' tinham seus nomes enunciados perante a mesa do cliente, com voz cantada. (TINHORÃO, 1998, p. 235)
\end{abstract}

\footnotetext{
${ }^{11}$ Uma lista delas pode ser conferida na Discografia Brasileira do Acervo Musical pertencente ao Instituto Moreira Salles (IMS), incluindo uma com o próprio Eduardo das Neves cantando e se acompanhando ao violão:

https://discografiabrasileira.com.br/en/music-recording/name/santos\%20dumont

Acesso em 05 jul. 2021.
} 
No trecho, o pesquisador entrelaça os nomes de Eduardo das Neves e Francisco Rosa ao indicar que ambos foram soldados do Corpo de Bombeiros do Rio de Janeiro ${ }^{12}$. Segundo a revista A Voz do Violão, Gadanho foi mesmo “um dos grandes 'capoeiras' do seu tempo e praça do Corpo de Bombeiros, onde aprendeu o violão, cantando em serenatas, o que lhe valeu a vida nômade dos circos.” (1931c, p. 30). De acordo com este relato, a atuação como bombeiro teria não somente antecedido a atividade circense, mas também oferecido o terreno propício para que o artista se preparasse para ela, em um ambiente no qual participava de cantorias e aprendia a tocar violão.

Seria uma coincidência que personagens como Eduardo das Neves, o "Crioulo Dudu", e Francisco Rosa, o "Gadanho", trabalhassem na mesma corporação e posteriormente a abandonassem para brilhar nos principais circos daquele tempo? É possível que a convivência de tais "capoeiras" nestes espaços corporativos tenha fermentado as bases para uma espécie de escola informal do instrumento (e de outras competências artísticas), vivenciada dentro e (sobretudo) fora das quatro linhas da corporação.

\begin{abstract}
Eduardo das Neves realmente fez parte do Corpo de Bombeiros, na $4^{\mathrm{a}}$ Companhia, como vários outros homens negros de sua condição entre o final de 1892 e o início de 1893. Mas lá não ficou muito tempo, como reconheceu. De fato, conforme registrou Jota Efegê [(1978)], memorialista da música popular, que teve acesso a seu prontuário, Dudu foi mesmo expulso do Corpo de Bombeiros após prisões sucessivas por frequentar fardado rodas de boêmios e chorões, ridicularizar superiores e fugir algumas vezes para tocar violão. Eduardo das Neves devia ter então 19 anos. (ABREU; DANTAS, 2020, p. 113-114).
\end{abstract}

No perfil que traça do palhaço, a revista $A$ Voz do Violão afirma que Gadanho "fazia o sucesso que mais tarde veio fazer o saudoso Eduardo das Neves" (1931c, p. 30), sugerindo que aquele possivelmente alcançara fama nos picadeiros antes de seu colega de corporação, uma hipótese ainda não passível de comprovação. O que se sabe é que ambos já brilhavam nos picadeiros a partir do último decênio do século XIX, pelo menos,

\footnotetext{
12 Tinhorão escreve que Eduardo das Neves foi expulso da corporação em 1893, passando a se dedicar exclusivamente ao circo: "Foi certamente essa aptidão para as artes populares - a ginga de corpo necessária à desconjuntada dança da chula, o gosto pelo canto e 'dar mão à lira' no violão - o que explicaria o fato de, já no Rio de Janeiro, ao ser expulso do Corpo de Bombeiros em 1893, o 'crioulo Dudu das Neves' ter resolvido entrar para a 'companhia equestre', ou seja, para a vida circense." (TINHORÃO, 2001, p. 74).
} 
já que as primeiras notícias da atuação ou do sucesso de ambos remontam à década de 1890.

Mas não foi só. Giacomo Bartoloni (2000, p. 99-100), ao mencionar a importância do circo como um espaço de atuação profissional decisivo para os músicos do período, deixa-nos saber que o palhaço Gadanho também atuou, em São Paulo, no celebrado Circo-teatro ${ }^{13}$ François:

\begin{abstract}
Para o músico popular, havia as apresentações em circos espalhados pela cidade [de São Paulo]. A música popular era cantada por palhaços chamados de palhaços de cara branca - e por cantores populares como Paraguassú e violonistas como Garoto que se apresentaram no Circo Piolim. O próprio palhaço Piolim tocava violão e bandolim pois, além da sua função cômica, também cantava modinhas. Tínhamos também o palhaço Gadanho, do Circo François [...].
\end{abstract}

Esta informação é ratificada no jornal paulistano Diário da Noite, já no início da década de 1970, em matéria de tom saudosista abordando "as grandes organizações circenses" que "exibiram-se com êxito na capital de São Paulo e deixaram o seu nome na história do circo em nossa terra", dando destaque, logo no início do texto, aos "famosos circos: Spinelli, Irmãos Queirolo, Olimecha, Alcebíades, Casali, Clementino, Americano e o François, onde pontificava o palhaço Gadanho, que era um "ás do violão". (DIÁRIO DA NOITE, 1970, p. 5 [2 $2^{\circ}$ caderno]). Das companhias listadas, chama a atenção que Gadanho tenha atuado como palhaço em pelo menos quatro delas (Spinelli, François, Clementino e Americano).

Coadunada com sua fama de "excêntrico", esta imagem de "ás" do instrumento parece ter surgido inicialmente no livro Belenzinho, 1910: retrato de uma época, de Jacob Penteado. Ao mencionar os diversos circos em atuação em São Paulo na primeira década do século XX, o autor ratifica que no Circo François havia o palhaço Benjamim de Oliveira, "emérito violonista e cantor apreciável"14, além de outro palhaço, de nome Gadanho, que era um "ás do violão." (2003 [1962], p. 170). Não se sabe ao certo por quantos anos Francisco Rosa permaneceu na companhia, mas, se sua atuação foi registrada no decênio inicial dos novecentos, provavelmente o palhaço também rodou

\footnotetext{
13 "Nesta modalidade de circo, o espetáculo circense é estruturado em duas partes. Na primeira são apresentados os números de variedades, como acrobacia, trapézio, corda, etc. [incluindo números musicais]. Na segunda parte são realizadas apresentações teatrais, destacando-se as pantomimas, farsas, comédias e dramas". (COSTA, 2010, p. 111).

${ }^{14}$ Ver mais sobre a história do palhaço Benjamim em: (SILVA, 2003).
} 
diversas regiões brasileiras com a trupe. O premiado Circo François ${ }^{15}$ era um dos picadeiros que detinha melhor elenco/estrutura e sua presença foi anotada, naquela década, em diversas apresentações que alcançaram estrondoso sucesso de público e crítica em estados do sul e sudeste, dentre os quais Paraná ${ }^{16}$, Rio de Janeiro ${ }^{17}$, Rio Grande do Sul $^{18}$, São Paulo ${ }^{19}$ e Santa Catarina:

Figura 23. Anúncio da função do Circo François em Florianópolis (SC), em novembro de 1906.

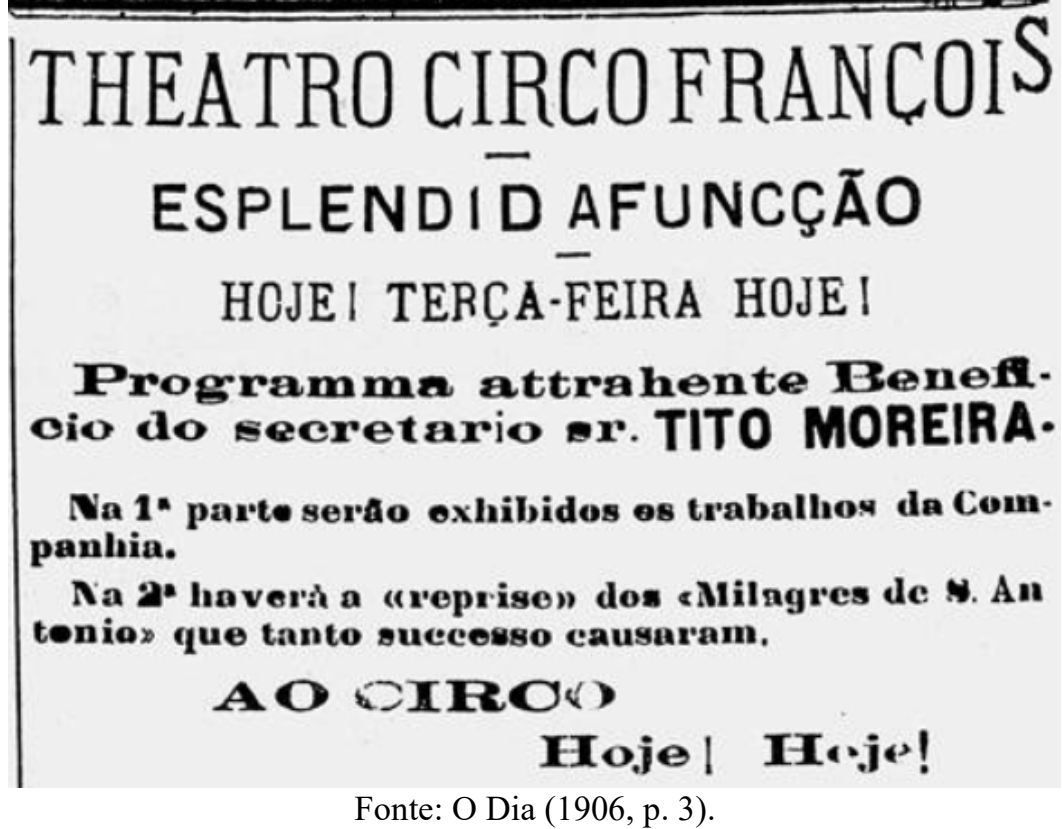

O trabalho no circo François é mais um ponto de aproximação entre Eduardo das Neves e Francisco Rosa, já que, de acordo com Costa (2010, p. 111), Dudu integrou o elenco da companhia, em 1905, "cantando suas modinhas no violão" e "figurando nas

\footnotetext{
${ }^{15}$ Em novembro de 1904, o jornal carioca Rio-Nú informa que "O Circo François vai ser premiado pelo Conservatório do Amparo com a medalha de 1838." (1904, p. 3).

16 "Realizou-se ontem a estreia do Circo François. [...] Todos os trabalhos foram bastante apreciados. A concorrência foi enorme, e às 8 horas da noite as vastas bancadas encontravam-se repletas. Sábado haverá nova função". (A NOTÍCIA, 1906, p. 2).

17 "Com deslumbrante função, estreia hoje o Circo François, sendo executados os mais difíceis trabalhos de ginástica e acrobacia pelo numeroso elenco da companhia. Interessantes palhaços e clowns lá estarão a postos, para fazer [rir?] grande os inúmeros espectadores.” (JORNAL DO BRASIL, 1903g, p. 8).

18 "Notas Alegres - Circo François [...] continua a deliciar, com franco sucesso de aplausos e bilheteria, os seus numerosíssimos frequentadores, entre os quais se conta a fina flor da sociedade porto-alegrense, que tem afluído aos espetáculos, pela curiosidade de apreciar esplendidos e arriscados trabalhos de equilíbrio, força, equestres e outros. [...] A Companhia é boa e está nas condições de merecer o acolhimento e a proteção do generoso público desta adiantada Capital. Ao circo François, todos!” (O PALADINO, 1909, p. 4).

19 "Continuam a trabalhar nesta cidade: [...] a companhia do circo François [com] espetáculos concorridos.” (CORREIO PAULISTANO, 1904a, p. 3).
} 
pantominas." ${ }^{20} \mathrm{Na}$ mesma década, portanto, as lonas do Circo François abrigaram três dos mais representativos palhaços do período vinculados ao instrumento: Benjamim de Oliveira, Eduardo das Neves e Gadanho. É possível, inclusive, que tenham protagonizado alguns espetáculos juntos, já que os anúncios nos jornais recorrentemente se referem, no plural, ao elenco de "clowns musicais" da companhia. (A CAPITAL, 1903, p. 4). Independente da hipótese, foi por sua atuação nos picadeiros deste circo que Francisco Rosa ganhou o epíteto que mais deflagra a sua proximidade com o instrumento de seis cordas: o "ás do violão".

Alguns anos depois, sua presença seria novamente registrada em São Paulo ao atuar no elenco do Circo Clementino, outra importante companhia do período e que abrigou, nas duas primeiras décadas do século XX, alguns "palhaços trovadores" que, utilizando largamente o violão, obtiveram sucesso na função: Caetano, Santos e sobretudo Serrano ${ }^{21}$. Em $1^{\text {o }}$ de julho de 1911, o circo protagonizou um espetáculo muito concorrido na capital paulista, apresentando um variado programa no qual "os clowns Seicel, Carrapatinho, Gadanho, Lopes e Santos fizeram rir os assistentes com os seus impagáveis trabalhos." (CORREIO PAULISTANO, 1911, p. 8). Neste mesmo ano, o Circo Clementino produziu, no Rio de Janeiro, o drama cômico Muzolino e a pantomima Serra Morena, este último com os irmãos Pery no elenco (SILVA, 2007, p. 331). São indícios de que Gadanho também pode ter feito eventuais apresentações com a companhia na então capital federal.

\footnotetext{
20 "Em 14 de janeiro de 1905, já aparece um cartaz do Circo François, como Circo-Teatro François, anunciando a presença de Eduardo das Neves cantando suas modinhas no violão, assim como figurando nas pantomimas, entre as quais o drama Os bandidos da Serra Morena". (COSTA, 2010, p. 111). Citando o livro de Vicente de Paula Araújo - Salões, circos e cinemas de São Paulo (1981, p. 115) -, Tinhorão ratifica a informação, inclusive indicando que, em uma das encenações desse drama, um curioso incidente quase tirou a vida do palhaço: E quando integrante do elenco do Circo-Teatro François, Eduardo das Neves estava destinado a viver ainda como ator, na noite de 21 de janeiro de 1905, na capital de São Paulo, um imprevisto que o tornaria - embora sem querer - o personagem central do que hoje se poderia classificar de um autêntico happening teatral: numa cena de tiroteio do drama Os bandidos da Serra Morena, alguém trocou as balas de festim do revólver de um comparsa, e o ator-cançonetista levou um tiro de verdade. Por sorte, segundo o legista, 'o projétil varou a pele e os tecidos musculares adjacentes, saindo pelo lado das costas, parecendo não ter penetrado a cavidade torácica', e já em março Eduardo das Neves podia voltar ao palco como personagem central de uma função em seu 'benefício', em que foram cantados '22 números de músicas escritas pelo beneficiado'." (TINHORÃO, 2001, p. 77).

21 "Durante boa parte do ano de 1902 e início do seguinte, tanto na capital paulista quanto em algumas cidades do interior do Estado, além de Benjamim de Oliveira, outro artista disputava as atenções dos jornais e do público. Não foi possível localizar muitas informações a seu respeito, somente que seu nome era Serrano e que trabalhava no Circo Clementino, onde era anunciado como 'palhaço-trovador' e muito apreciado nas 'modinhas ao violão e nas chulas Sapateadas'.” (SILVA, 2007, p. 192).
} 
$\mathrm{Na}$ década de 1910, a carreira de Gadanho entra paulatinamente em declínio. Apesar de suas qualidades como barítono, cançonetista e violonista terem sido recorrentemente louvadas nas fontes que suscitamos, o palhaço, por alguma razão desconhecida, não adentrou no emergente universo da fonografia brasileira, o que ocorrera com a maioria de seus pares ilustres. Somado ao avanço da idade, o fato parece ter tido um impacto negativo em sua popularidade, consequentemente, nas oportunidades de trabalho que recebia (ou que deixava de receber) das melhores companhias, justamente aquelas que anunciavam seus espetáculos e roteiros nos jornais. Em grupos circenses, a última de suas apresentações que suscitamos ocorreu em maio de 1915, no Circo NorteAmericano, instalado no bairro do Engenho Novo, no Rio de Janeiro. Na ocasião, ao lado de Victorino, Gadanho, então com 43 anos, foi apresentado como um dos cançonetistas da companhia.

Figura 24. Programa do Circo Norte-Americano em 15 e 16 de maio de 1915, no Rio de Janeiro, com a participação de Gadanho como cançonetista.

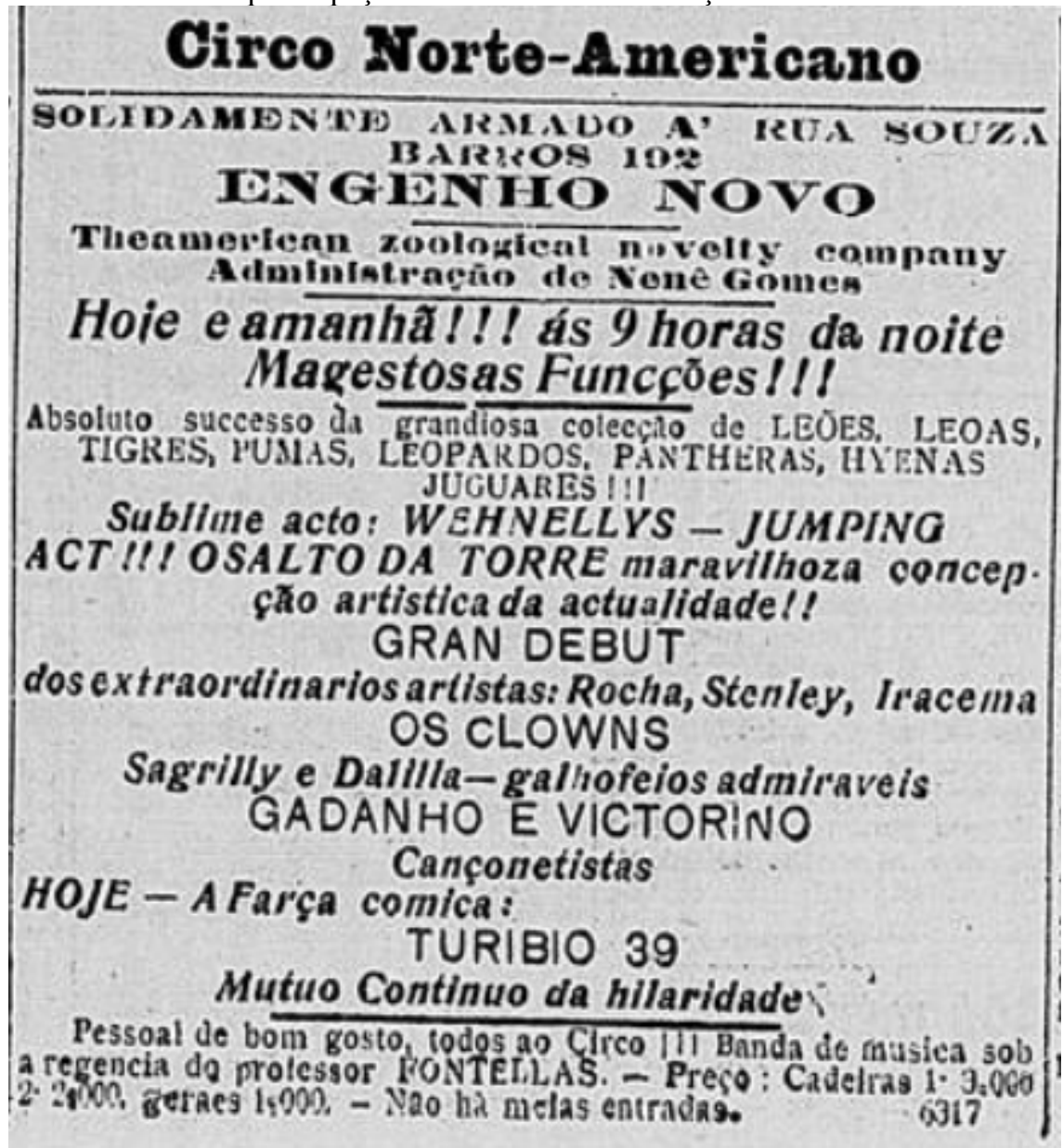

Fonte: A Época (1915, p. 8). 
Ao constatar o final de carreira sem brilho de Gadanho, a melancolia anotada nas páginas da revista $A$ Voz do Violão (1931c, p. 30) no início da década de 1930 - “já não é mais o picadeiro com a areia refulgindo à luz do acetileno" - já se esboça em um raro registro do músico visitando a redação de um jornal durante o carnaval carioca de 1918 (a visita de artistas às redações durante o período carnavalesco - ou mesmo no calendário normal - era um costume da época), ocasião em que, a despeito de suas qualidades como cantador de modinhas e exímio tocador de violão, o "bicho batuta" Francisco Rosa Gadanho é apresentado como "um cantador avulso", sem vinculação, como outrora, a quaisquer das companhias circenses mais afamadas do período.

Figura 25. Registro da passagem de Gadanho na redação de um jornal carioca em 11 de fevereiro de 1918, em nota que consta na coluna "Carnaval na Gazeta".

\begin{tabular}{|c|}
\hline 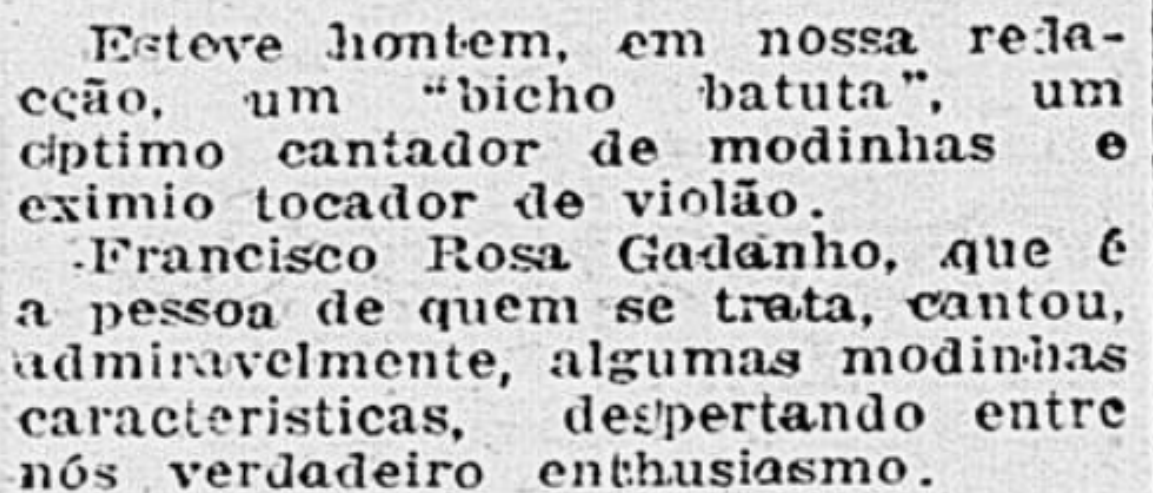 \\
\hline
\end{tabular}

Fonte: Gazeta de Notícias (1918, p. 5).

Sem família, envelhecido e esquecido profissionalmente, Gadanho não teve os últimos anos de sua trajetória documentados. Ao que tudo indica, nem uma nota de falecimento foi publicada nos jornais do Rio de Janeiro (ou de outros estados) ${ }^{22}$, ação comum no período e que geralmente era encomendada por familiares ou pessoas próximas, em mais um sinal do quase total isolamento experienciado pelo palhaço no fim

\footnotetext{
${ }^{22}$ Não encontramos quaisquer fontes hemerográficas indicando a data de sua morte, apesar de realizarmos buscas na hemeroteca digital da Biblioteca Nacional, com diversas combinações de palavras (incluindo o vocábulo "Gadanho" isolado), até a década de 1970. Não foi possível averiguar se o artista permaneceu continuamente no Brasil até a sua morte, é viável que tenha tido passagens profissionais esporádicas por outros países ou feito eventuais visitas ao seu país de origem (ou mesmo se estabelecido por lá ao final de sua vida). Indícios de que estas viagens podem ter ocorrido são registrados desde a década de 1900: em 18 de dezembro de 1907, por exemplo, através de um paquete italiano advindo de Genova e escalas, sabemos que um homem de nome Francisco Rosa desembarcou no Rio de Janeiro após 19 dias de viagem (JORNAL DO BRASIL, 1907, p. 5). Não se pode assegurar que se trata do mesmo personagem, mas talvez seja um sinal de que Gadanho, já instalado no Brasil, possa ter feito algumas viagens de ida e volta à sua terra natal ou passado os anos finais de sua vida por lá.
} 
de sua vida: "Só, não: tem um violão que o acompanha há trinta anos. Na glória e na miséria", como sugeriu poeticamente a revista A Voz do Violão (1931c, p. 30).

Um "ás do violão" que acabou a sua carreira por volta da década de 1930, sem glamour (como, aliás, a maioria de seus pares) e sobrevivendo no Rio de Janeiro cantando números musicais às mesas de um modesto estabelecimento de massas, enquanto o cardápio com a lista dos pratos do dia era anunciado aos gritos pelo caixeiro. Mais do que um retrato da luta pela sobrevivência enfrentada pelos palhaços músicos do período, Gadanho, de certa forma, representa a junção prática e simbólica de algumas das camadas que compuseram o caldeirão multifacetado do violão brasileiro: um estrangeiro que desembarca em terras brasileiras, passa a trabalhar em espaços predominantemente ocupados por personagens de pouca renda, embrenhando-se dos cruzamentos entre danças europeias ainda em voga, tradições culturais afro-brasileiras e gêneros/subgêneros musicais emergentes. Em síntese, um imigrante do sul da Itália que chega ao Brasil na segunda metade do século XIX e passa a circular em ambientes socioculturais e profissionais dos mais diversos, trabalhando como agência, operário, soldado do corpo de bombeiros, mas também em circos afamados, cafés-cantantes e restaurantes baratos, absorvendo as bricolagens culturais que permitiram que, no início do século XX, ele se tornasse o compositor de um dos primeiros choros para violão solo de que se tem notícia no Brasil.

\section{3. “Quem dá mais, quem dá mais?” Vamos às considerações finais}

Ao remontar algumas das peças do quebra-cabeça que envolve a trajetória de Francisco Rosa Gadanho (o que inclui alguns dos contextos e circuitos nos quais esteve), constatamos que este personagem ocupou posições destacadas como palhaço profissional, integrando companhias reconhecidas (Spinelli, François, Clementino, Norte-Americano) e trabalhando diretamente com alguns dos circenses mais importantes que atuaram no Brasil entre fins do século XIX e primeiras décadas do XX, notadamente Rosita de la Plata, Benjamim de Oliveira e Eduardo das Neves.

Sua fama como cançonetista e instrumentista foi recorrentemente ratificada nos jornais da época, justificando o recebimento de epítetos como "lacrimejador de modinhas" e "ás do violão". Tais habilidades lhe renderam a denominação de palhaço 
"excêntrico", termo que nominava o artista que possuía alguma capacidade diferenciada em instrumentos musicais. Não parece, por isso, que a imprensa tenha reconhecido seus méritos por mero encômio: "exímio tocador de violão" ou ainda o violonista furioso que tocava a “todo vapor". Mesmo em 1931, já com a idade avançada, em fim de carreira e empunhando um violão velho, de cordas gastas e com 30 anos de histórias, a revista $A$ Voz do Violão não deixa de se referir a ele como "bom violonista".

A pergunta que se faz é como este personagem, inserido na rede dos melhores circos e ocupando espaços profissionais ladeado por seus pares mais ilustres, acabou tendo a sua existência obliterada, sem qualquer reconhecimento mais detido, especialmente a partir de princípios da década de 1930. Alguns fatores somados podem justificar, ao menos parcialmente, este ocaso:

1) $\mathrm{O}$ circo brasileiro enfrentou algumas mudanças de paradigmas nas primeiras décadas do século XX, dentre elas, a consolidação do circo-teatro como possível alternativa para as crises econômicas e os custos altos de manutenção do aparato circense (sobretudo com os animais), processo que ocorreu desde meados dos oitocentos e se acentuou no início dos novecentos, privilegiando um tipo de "palhaço-ator" que não era o perfil mais característico de Gadanho, artista que até atuou em algumas produções do gênero, mas era mais reconhecido como cançonetista e violonista.

2) Ainda no início do século XX, surgem ou se consolidam “inovações tecnológicas - eletricidade, telégrafo, telefone, transportes coletivos" que redimensionam a relação de produção e consumo dos bens culturais: "todas essas tecnologias foram fundamentais para a implementação de pelo menos duas importantes indústrias: a do cinema e a do disco" (SILVA, 2007, p. 132). Acontece que Gadanho permaneceu à margem de ambas (e aqui incluiremos também o rádio), o que não ocorrera com seus pares consagrados, aparentemente melhor adequados aos meios de produção dos novos tempos. Como consequência, não há registros de sua voz ou violão nas então emergentes fonografia e radiofonia brasileiras, tampouco indícios de que tenha trabalhado como músico de cinema, fatores fundamentais para que seus colegas, por exemplo, prolongassem a fama alcançada nos circos e deixassem registros perenes de seus trabalhos, especialmente através dos discos ${ }^{23}$.

\footnotetext{
23 "Com o aparecimento do disco e, logo depois, do cinema e do rádio, o papel de homem-espetáculo dos palhaços dos circos de duas partes mudou um pouco. Após terem que concorrer com a atração das projeções de filmes mudos - como na década de 1920 acontecia no interior de Goiás com o Circo-Pavilhão Mineiro,
} 
3) Não bastasse, é provável que Gadanho tenha tido um final de vida solitário, sem contato com os antigos parentes italianos e também já não contando mais com a presença da esposa e do filho brasileiros, falecidos antes. Sem herdeiros, é quase certo que seus documentos, arquivos e memórias tenham se dissipado com a sua morte. Não fossem as fontes hemerográficas suscitadas e a matéria da revista $A$ Voz do Violão publicada em 1931, quase nada saberíamos deste personagem, importante para o violão pelas atividades circenses que desempenhou com o instrumento em punho (sendo um dos mais representativos palhaços músicos do período), mas também por ter nos legado um dos choros para violão mais antigos de que se tem notícia no Brasil: Caranguejo, composto antes de 1912, pelo menos.

Ao apresentar o manuscrito de Caranguejo e instilar um primeiro olhar sobre os dados biográficos e as atividades profissionais de Gadanho, este artigo intentou não somente recolocá-lo na pauta dos estudos brasileiros para violão, mas também chamar atenção para como, no Brasil, o circo foi possivelmente um espaço sociocultural importante no percurso histórico do instrumento desde meados do século XIX, cumprindo um papel que teve reverberações na constituição, recriação e/ou disseminação de um repertório para violão, seja como acompanhamente ou solista (conforme demonstra a peça apresentada), temas aqui fagulhados e que merecem ser aprofundados em futuras pesquisas.

\section{Referências Bibliográficas}

ABREU, Martha; DANTAS, Carolina. Monteiro Lopes e Eduardo das Neves: histórias não contadas da Primeira República. Niterói: Eduff, 2020.

AMORIM, Humberto; MOTTA, Jefferson. L. G.; PASCHOITO, Ivan; PRANDO, Flavia. Colibri e Caranguejo: genealogia e edição de dois choros pioneiros para violão. Orfeu, Florianópolis, v. 6, n. 1, p. 1-34, 2021.

ANTUNES, Gilson Uehara. Américo Jacomino Canhoto e o desenvolvimento da arte solística do violão em São Paulo. 2002. Dissertação (Mestrado em Musicologia) - Escola de Comunicação e Artes, USP, São Paulo, 2002.

ARAÚJO, Vicente de Paula Araújo. Salões, circos e cinemas de São Paulo. São Paulo: Editora Perspectiva, 1981.

cujo gerador de luz própria permitia incluir entre as atrações 'uma boa máquina de projetar filmes' -, viram chegar logo depois os artistas tornados populares pelo disco, convidados para apresentações especiais na qualidade de 'cartazes'. (TINHORÃO, 2001, p. 80). 
BARTOLONI, Giacomo. Violão: a imagem que fez escola. São Paulo 1900-1960. 2000. Tese (Doutorado em História) - Universidade Estadual Paulista, Faculdade de Ciências, História e Letras de Assis, Assis, 2000.

BOLOGNESI, Mário Fernando. Palhaços. São Paulo: Editora Unesp, 2003.

CORTEZ, Melchior. Colibri. Buenos Aires: Casa Romero y Fernandez, [s.d.]. Partitura.

COSTA, Eliene B. A. Um estudo das comédias mágicas $O$ Chico e o Diabo e Os Irmãos Jogadores, de Benjamim de Oliveira. Repertório, Salvador, v. 13, n. 15, p. 111-128, 2010.

CUNHA, Maria Clementina Pereira. Ecos da folia: uma história social do Carnaval carioca entre 1880 a 1920. São Paulo: Companhia das Letras, 2001.

DAMASCENO, Athos. Palco, salão e picadeiro em Porto Alegre no século XIX: contribuições para o estudo do processo cultural do Rio Grande do Sul. Rio de Janeiro: Editora Globo, 1956.

EDMUNDO, Luiz. O Rio de Janeiro do meu tempo. Rio de Janeiro: Imprensa Nacional, 1938.

EFEGÊ, Jota. Figuras e coisas da música popular brasileira, vol. I. Rio de Janeiro: Mec/Funarte. 1978.

FERREIRA, Suzana Cristina de Souza. Adhemar Gonzaga e a Cinédia: imagens de um país que dança. Tese (Doutorado em História). Faculdade de Filosofia e Ciências Humanas. Belo Horizonte: Universidade Federal de Minas Gerais, 2006.

GUERRA, Antônio. Pequena História de Teatro, Circo, Música e Variedades em São João del Rei: 1717 a 1967. [Juiz de Fora], [Of. Da Sociedade Propagadora Esdeva], 1968.

PARAGUASSÚ. Org. Neide Lopes Ciarlariello. Baú da Saudade. São Paulo: Matarazzo, 2016.

PENTEADO. Jacob. Belenzinho, 1910. São Paulo: Carrenho Editorial, 2003 [1962].

PINTO, Alexandre Gonçalves. Choro: reminiscências dos chorões antigos. $3^{\text {a }}$ ed. comentada, revisada e ilustrada. Rio de Janeiro: Acari Records, 2014 [1936].

SILVA, Erminia. O circo: sua arte e seus saberes: o circo no Brasil do final do século XIX a meados do XX. (Dissertação de mestrado) - Instituto de Filosofia e Ciencias Humanas, UNICAMP, 1996.

SILVA, Erminia. As múltiplas linguagens na teatralidade circense: Benjamim de Oliveira e o circo-teatro no Brasil no final do século XIX e início do XX. (Tese de doutorado) - Instituto de Filosofia e Ciencias Humanas, UNICAMP, 2003. 
SILVA, Erminia. Circo Teatro: Benjamim de Oliveira e a teatralidade circense no Brasil. São Paulo: Editora Altana, 2007.

TABORDA, Marcia. Violão e Identidade Nacional: Rio de Janeiro 1830/1930. Tese (Doutorado em História). Programa de Pós-Graduação em História Social. Rio de Janeiro: UFRJ/IFCS, 2004.

TINHORÃO, José Ramos. História social da música popular brasileira. Editora 34, 1998.

TINHORÃO, José Ramos. Cultura popular: temas e questões. São Paulo: Ed. 34, 2001. p.70.

TINHORÃO, José Ramos. Os sons que vêm da rua. São Paulo: Editora 34, 2005.

\section{Periódicos}

A CAPITAL, Rio de Janeiro, Ed. 530, 1 ago. 1903, p. 4.

A ÉPOCA, Rio de Janeiro (RJ), Ed. 994, 15 maio 1915, p. 8.

A FEDERAÇÃO, Porto Alegre, Ed. 123, 30 mai. 1900a, p. 2.

A FEDERAÇÃO, Porto Alegre, Ed. 134, 12 jun. 1900b, p. 2.

A FEDERAÇÃO, Porto Alegre (RS), Ed. 63, 17 mar. 1900c, p. 3.

A FEDERAÇÃO, Porto Alegre, Ed. 152, 3 jul. 1900d, p. 2.

A FEDERAÇÃO, Porto Alegre (RS), Ed. 166, 19 jul. 1902, p. 4.

A FEDERAÇÃO, Porto Alegre (RS), Ed. 134, 10 jun. 1903, p. 3.

A NOTÍCIA, Curitiba (PR), Ed. 241, 17 ago. 1906, p. 2.

A NOTÍCIA, Rio de Janeiro, Ed. 261, 25-26 out. 1898, p. 2.

A REPUBLICA, Curitiba, Ed. 57, 10 mar. 1904a, p. 2.

A REPUBLICA, Curitiba, Ed. 74, 30 mar. 1904b, p. 2.

A REPUBLICA, Curitiba, Ed. 82, 11 abr. 1904c, p. 2.

A VOZ DO VIOLÃO, Rio de Janeiro, Ano I, n. 1, fev. 1931a, p. 23.

A VOZ DO VIOLÃO, Rio de Janeiro, Ano I, n. 2, mar. 1931b.

A VOZ DO VIOLÃO, Rio de Janeiro, Ano I, n. 3, abril 1931c, p. 30.

CORREIO PAULISTANO, São Paulo (SP), Ed. 14849, 12 dez. 1904a, p. 3.

CORREIO PAULISTANO, São Paulo (SP), Ed. 14615, 22 abr. 1904b, p. 2.

CORREIO PAULISTANO, São Paulo, ano XLII, n. 14916. 18 fev. 1905, p. 2.

CORREIO PAULISTANO, São Paulo (SP), Ed. 17213, 2 jul. 1911, p. 8.

DIÁRIO DA TARDE, Curitiba (PR), Ed. 1531, 11 mar. 1904a, p. 1.

DIÁRIO DA TARDE, Curitiba (PR), Ed. 1532, 12 mar. 1904b, p. 1.

DIÁRIO DA TARDE, Curitiba (PR), Ed. 1554, 8 abr. 1904c, p. 2.

DIÁRIO DA TARDE, Curitiba (PR), Ed. 1555, 9 abr. 1904d, p. 2. 
DIÁRIO DA NOITE, O Circo Chegou, São Paulo, 13 jun. 1970, 2º caderno, p. 5.

DIÁRIO DE NOTÍCIAS, Música, Rio de Janeiro (RJ), Ed. 1007, 30 mar. 1933, p. 9.

GAZETA DE NOTÍCIAS, Rio de Janeiro, Ed. 42, 11 fev. 1918, p. 5.

JORNAL DO BRASIL, Rio de Janeiro (RJ), Ed. 234, 22 ago. 1903a, p. 2.

JORNAL DO BRASIL, Rio de Janeiro (RJ), Ed. 239, 27 ago. 1903b, p. 3.

JORNAL DO BRASIL, Rio de Janeiro (RJ), Ed. 241, 29 ago. 1903c, p. 3.

JORNAL DO BRASIL, Rio de Janeiro (RJ), Ed. 256, 13 set. 1903d, p. 10.

JORNAL DO BRASIL, Rio de Janeiro (RJ), Ed. 302, 29 out. 1903e, p. 3.

JORNAL DO BRASIL, Rio de Janeiro (RJ), Ed. 265, 22 set. 1903f, p. 6.

JORNAL DO BRASIL, Rio de Janeiro (RJ), Ed. 228, 16 ago. 1903g, p. 8.

JORNAL DO BRASIL, Rio de Janeiro, Movimento do Porto, Ed. 352, 18 dez. 1907, p. 5.

O COMMERCIO DE SÃO PAULO, São Paulo (SP), Ed. 4031, 15 abr. 1905, p. 3.

O DIA, Florianópolis (SC), Ed. 1715, 6 nov. 1906, p. 3.]

O FLUMINENSE, Niterói (RJ), Ed. 5242, 7 jul. 1903, p. 4.

O PALADINO, Porto Alegre (RS), Ed. 15, $1^{\circ}$ maio 1909, p. 4.

RIO-NÚ, Rio de Janeiro, Ed. 661, 5 nov. 1904, p. 3. 
